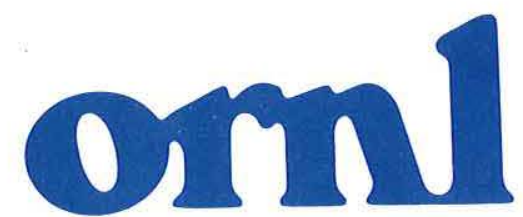

\section{OAK RIDGE \\ NATIONAL \\ LABORATORY}

MARTIN MARIETTAA
MARTIN MARIETTA ENERGY SYSTEMS LIBRARIES

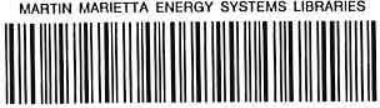

3 445ь 루길
ORNL-6317

(NVO/AEIC-306)

Sylvia S. Talmage

Betty D. Chilton

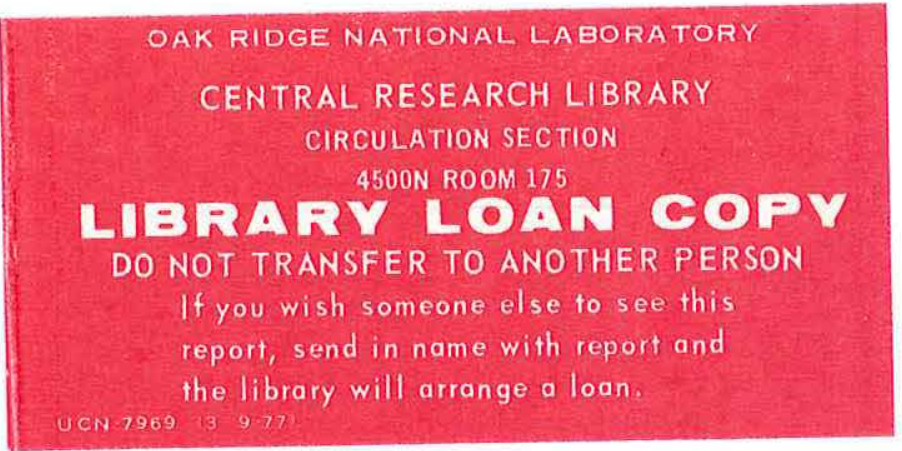

OPERATED BY

MARTIN MARIETTA ENERGY SYSTEMS, INC.

FOR THE UNITED STATES

DEPARTMENT OF ENERGY 
Printed in the United States of America. Available from National Technical Information Service

U.S. Department of Commerce

5285 Port Royal Road, Springfield, Virginia 22161

NTIS price codes-Printed Copy: A04 Microfiche A01

This report was prepared as an account of work sponsored by an agency of the United States Government. Neither the United States Government nor any agency thereof, nor any of their employees, makes any warranty, express or implied, or assumes any legal liability or responsibility for the accuracy, completeness, or usefulness of any information, apparatus, product, or process disclosed, or represents that its use would not infringe privately owned rights. Reference herein to any specific commercial product, process, or service by trade name, trademark, manufacturer, or otherwise, does not necessarily constitute or imply its endorsement, recommendation, or favoring by the United States Government or any agency thereof. The views and opinions of authors expressed herein do not necessarily state or reflect those of the United States Government or any agency thereot. 
ORNL-6317

NVO/AEIC-306

Biology Division

\title{
CLEANUP PROCEDURES AT THE NEVADA TEST SITE AND AT OTHER RADIOACTIVELY CONTAMINATED SITES INCLUDING REPRESENTATIVE COSTS OF CLEANUP AND TREATMENT OF CONTAMINATED AREAS
}

\author{
Sylvia S. Talmage \\ Betty D. Chilton
}

Information Research and Analysis

Nevada Applied Ecology Information Center

Date Published-September 1987

Prepared by the

OAK RIDGE NATIONAL LABORATORY

Oak Ridge, Tennessee 37831

operated by

MARTIN MARIETTA ENERGY SYSTEMS, INC.

for the

U.S. DEPARTMENT OF ENERGY

under Contract No. DE-AC05-84OR21400

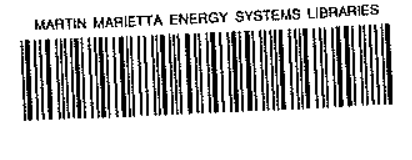

34456 마길 

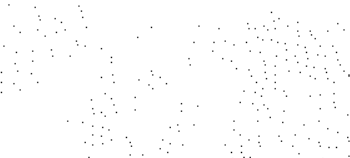


\section{CONTENTS}

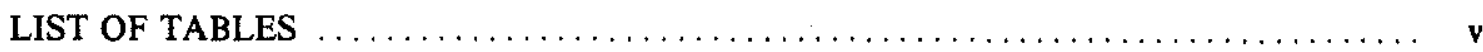

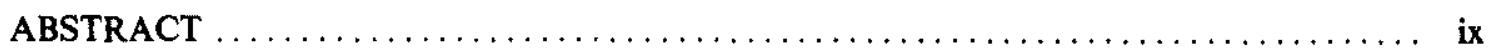

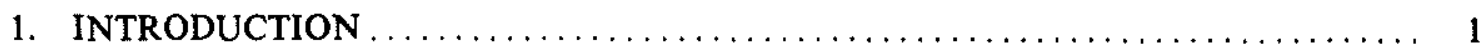

2. CLEANUP PROCEDURES AT THE NEVADA TEST SITE AND OTHER RADIOACTIVELY CONTAMINATED SITES $\ldots \ldots \ldots \ldots \ldots \ldots \ldots, \ldots, \ldots, \ldots$

2.1 CLEANUP PROCEDURES AT THE NEVADA TEST SITE $\ldots \ldots \ldots \ldots \ldots \ldots \ldots, 3$

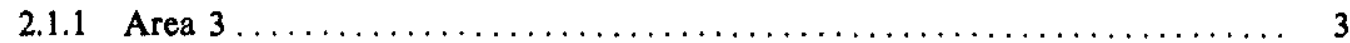

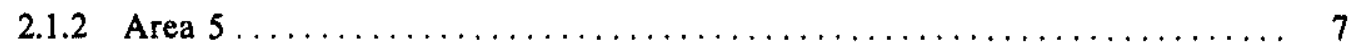

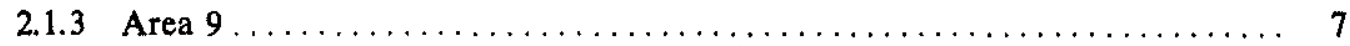

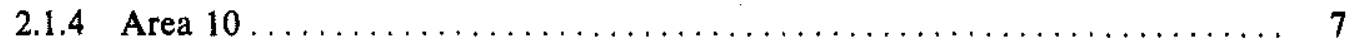

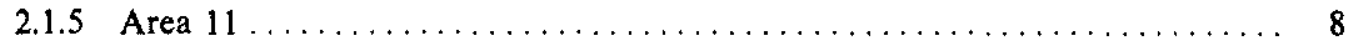

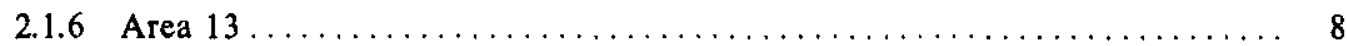

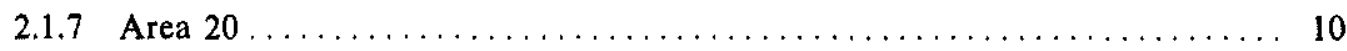

2.1.8 Nuclear Rocket Development Station (Area 25) ................. 10

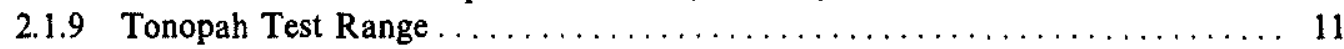

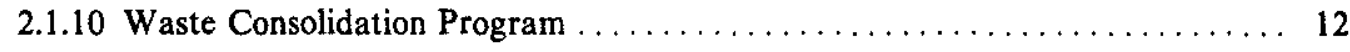

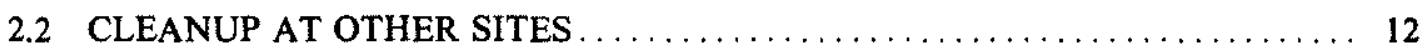

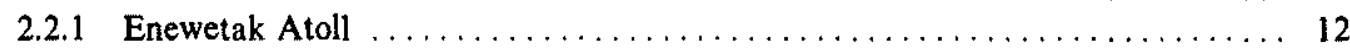

2.2 .2 Nonweapon Detonations . . . . . . . . . . . . . . . . . . . . . 15

2.2 .3 Accidental Releases..................................... 15

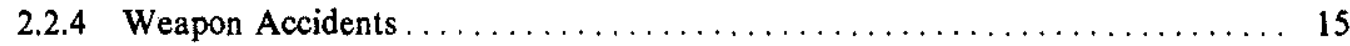

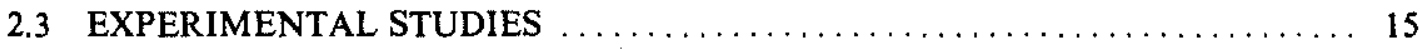

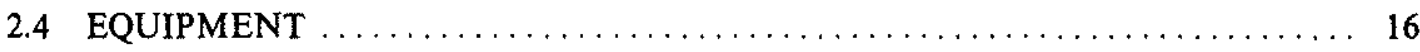

2.5 CHEMICAL AND PHYSICAL METHODS $\ldots \ldots \ldots \ldots \ldots \ldots \ldots \ldots \ldots \ldots$

3. REPRESENTATIVE COSTS OF CLEANUP AND TREATMENT OF

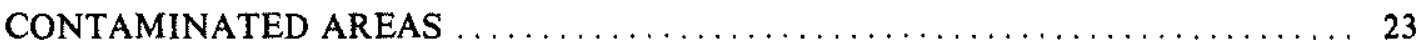

3.1 ESTIMATING COST PER UNIT OPERATION FOR OTHER

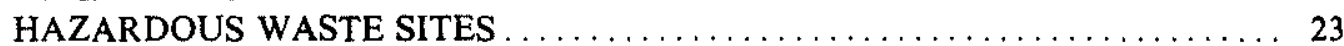

3.2 COSTS FOR SITE STABILIZATION, LONG-TERM CARE, AND WASTE

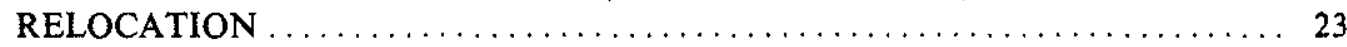

3.3 COSTS FOR STABILIZATION OF FINE-SIZED MINERALS $\ldots \ldots \ldots \ldots \ldots 25$

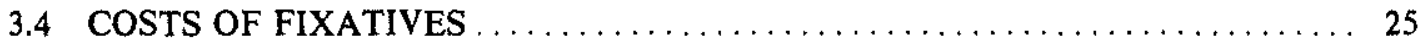

3.5 COSTS OF URANIUM MILL TAILINGS STABILIZATION $\ldots \ldots \ldots \ldots \ldots \ldots 26$

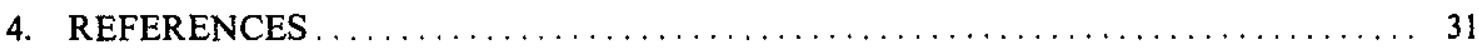

Appendix A. ADDITIONAL PUBLICATIONS CONTAINING COST DATA ........ 37

Appendix B. COMPONENT COST DATA FOR LANDFILL AND SURFACE IMPOUNDMENT OPERATIONS $\ldots \ldots \ldots \ldots \ldots \ldots \ldots \ldots \ldots \ldots$ 
$i$ 


\section{LIST OF TABLES}

1. Cleanup and treatment methods at the Nevada Test Site $\ldots \ldots \ldots \ldots \ldots \ldots \ldots \ldots$

2. Estimates of the amount of soil removal necessary to decontaminate a $15-\mathrm{cm}$ depth

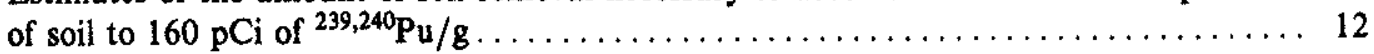

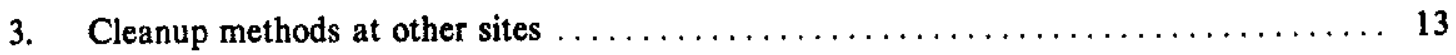

4. Decontamination achieved by scraping soil surface following various treatments

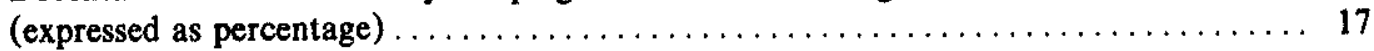

5. Equipment used for cleanup of radioactivity contaminated sites $\ldots \ldots \ldots \ldots \ldots \ldots, 18$

6. Soil stabilizers for radioactively contaminated sites $\ldots \ldots \ldots \ldots \ldots \ldots \ldots \ldots \ldots$

7. Estimated costs of site stabilization for an arid western site $\ldots \ldots \ldots \ldots \ldots \ldots \ldots 24$

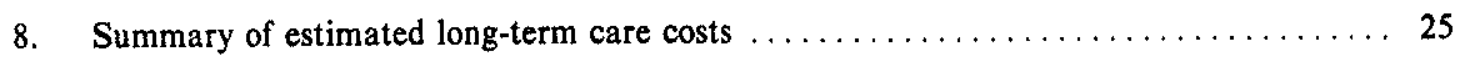

9. Estimated costs of relocation of all the waste from a conventional burial trench

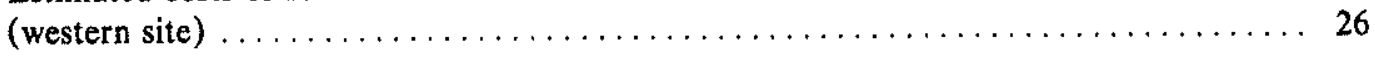

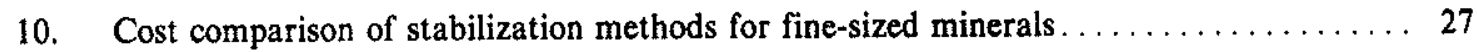

11. Cost estimates for fixatives suitable for use on radioactively contaminated surfaces .... 28

12. Estimated dollar costs to move contaminated soil ..................... 29

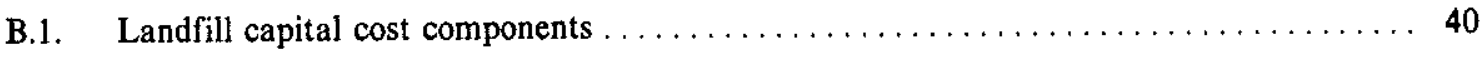

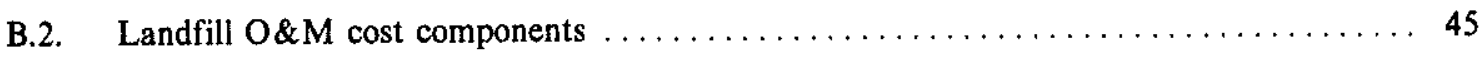

B.3. Surface impoundment of capital cost components $\ldots \ldots \ldots \ldots \ldots \ldots \ldots \ldots \ldots \ldots$

B.4. Surface impoundment of overhead and maintenance $\ldots \ldots \ldots \ldots \ldots \ldots \ldots \ldots \ldots$ 
s 


\section{ACKNOWLEDGEMENTS}

This publication is made possible through funding from the Nevada Applied Ecology Group.

Special appreciation is given to Dr. Tsuneo Tamura for his contribution in reviewing this report, to Pat Quiggins for her assistance in editing, and to Dorla Arnwine for typing of the manuscript. 


\begin{abstract}
This review summarizes available information on cleanup procedures at the Nevada Test Site and at other radioactively contaminated sites. Radionuclide distribution and inventory, size of the contaminated areas, equipment, and cleanup procedures and results are included. Information about the cost of cleanup and treatment for contaminated land is presented. Selected measures that could be useful in estimating the costs of cleaning up radioactively contaminated areas are described.
\end{abstract}

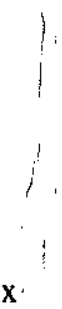




\section{INTRODUCTION}

The Nevada Applied Ecology Information Center (NAEIC) at Oak Ridge National Laboratory (ORNL) has provided information support to the Nevada Applied Ecology Group (NAEG) since January 1972. In the early years, information collected for the first data file emphasized the movement of plutonium through the environment, particularly those studies pertaining to safety shot and nuclear weapon detonation sites on the Nevada Test Site (NTS). The data base was soon expanded to include environmental and laboratory studies of all the transuranics.

Since October 1977, NAEIC has concentrated its efforts on identifying and analyzing documents on the cleanup and treatment of radioactively contaminated land. In September 1982 a bibliography (Fore, Faust, and Brewster 1982) was published; it contains 472 references on the site specific methods of cleanup of radioactively contaminated sites. In support of the NAEG, particular attention was paid to cleanup procedures used at NTS.

This report summarizes available information contained in the bibliography on cleanup. procedures at NTS. Radionuclide distribution and inventory, size of the contaminated areas, equipment and cleanup procedures, cleanup results, and costs, where available, are included. The largest amount of available information is for safety shot areas that are candidates for remedial action. These sites-in Areas 5, 11, and 13 at NTS and at the DOUBLE TRACK and CLEAN SLATE 1, 2, and 3 sites at the Tonopah Test Range-have been researched by the NAEG. At these sites, chemical explosives were detonated in close proximity to arrangements or assemblies of plutonium and/or uranium. According to Kordas and Anspaugh (1982), the total area of these 10 sites is $11.4 \mathrm{~km}^{2}$. For comparative purposes, cleanup of radioactively contaminated soil following testing or accidents at other sites is described. Two applicable experimental studies are also discussed. Several chemical and physical methods of soil cleanup are being researched, and some of these methods are described. An inventory of equipment used for physical cleanup is included.

A survey of the literature on the cost of cleanup and treatment for contaminated land follows the sections describing cleanup procedures. Available data are scarce, so it is difficult to compare methods and/or costs or to conclude much of value from them. Most of the available data are for estimated rather than actual costs. Some of the information was published in the mid-1970s or earlier, and no allowance has been made for inflation since that time. This section consists of information about a few selected measures that, although not directly related to radioactive contamination in all cases, might prove useful in estimating the costs of cleaning up radioactively contaminated areas. Tables of data are included on (1) cost for each unit operation, (2) estimated costs of site stabilization, (3) estimated long-term care costs, (4) estimated cost of relocation of the radioactive material, (5) cost comparison of stabilization methods for fine-sized materials, and (6) cost estimates for fixatives used on radioactively contaminated surfaces. To avoid comparing unlike conditions, only data that can be applied to arid regions have been included. Additional references containing cost data (other than those cited in this report) are provided in Appendix A. 


\section{CLEANUP PROCEDURES AT THE NEVADA TEST SITE AND AT OTHER RADIOACTIVELY CONTAMINATED SITES}

\subsection{CLEANUP PROCEDURES AT THE NEVADA TEST SITE}

The Reynolds Electrical and Engineering Co., Inc., (REECo) has been in charge of radiation safety at NTS for many years. A report from REECo files on land decontamination, specificaliy alpha decontamination, by Brown et al. (1964) is quoted by Wallace and Romney (1975): "Land area decontamination techniques at NTS vary with the contaminant and with future plans for use of the area. If immediate reuse is required, the contaminant is completely removed from the area and transported to a waste disposal site. If there are no plans for area use, intermediate procedures may be used to fix or seal the contaminant in place to inhibit resuspension or redistribution."

According to Wallace and Romney (1975), windrows that can be picked up for later disposal have been a very common means of decontamination at NTS. This method and other cleanup methods used at NTS are summarized in Table 1.

\subsubsection{Area 3}

Kordas and Anspaugh (1982) list 30 events in Area 3. Six of these were safety experiments.

Following shot COULOMB C (Operation Plumbbob), which took place on on December 9 , 1957 (Miller 1958), the Civil Effects Test Operation Exercise CEX-57.1 was carried out. The objective of the exercise was to carry out and evaluate decontamination methods in a fallout area with low levels of radioactive contamination. The cleanup procedure began $1 \mathrm{~d}$ after the shot. Radiation levels were between 30 and $40 \mathrm{mrad} / \mathrm{h}$. Data were obtained on reclamation of land areas scraped with a motorgrader, on fire hosing and scrubbing a concrete-slab roof, and on fire hosing a composition roof. Scraped soil was pushed away from the buildings and into windrows; the depth of cut was set to $1 \frac{1 / 2}{2}$ in. $(3.8 \mathrm{~cm})$. The decontamination effectiveness was reported in terms of the fraction (FR) of contamination remaining after cleanup. Radiation intensity in $\mathrm{mrad} / \mathrm{h}$ at the ground surface around Building $A$ decreased from an initial 30.5 to $6.1 \mathrm{mrad} / \mathrm{h}$ after scraping, giving a decontamination ratio, FR, of $6.06 / 30.5$ or 0.2 . Decontamination ratios for other surfaces are contained in Table 1.

Decontamination of other event sites in Area 3 was undertaken in 1960 (REECo Decontamination Report-Area 3, as cited in Brown et al. 1961). Reduction of surface contamination was accomplished by thin-layer windrowing of the top soil. Contamination was fixed by spraying a hot road-oil spray over the windrows.

Radioisotopes found in soil samples from Area 3 include ${ }^{241} \mathrm{Am},{ }^{60} \mathrm{Co},{ }^{152} \mathrm{Eu}$, and ${ }^{137} \mathrm{Cs}$ (Fritzsche 1982). The Fritzsche report documents seven major contaminated areas, which are defined on aerial isopleth maps; two are waste dumps, one of which has since been removed. Locations of maximum measured exposure, identified isotopes, and associated event names are given. For example, the inventories of ${ }^{60} \mathrm{Co},{ }^{152} \mathrm{Eu}$, and ${ }^{137} \mathrm{Cs}$ in the surface soil of a $3.1 \mathrm{~km}^{2}$ area associated with events HARRY and HORNET are 0.3, 43.0, and $0.4 \mathrm{Ci}\left(1.1 \times 10^{10}, 1.6 \times 10^{12}\right.$, and $1.5 \times 10^{10} \mathrm{~Bq}$ ). Americium-241, which is found throughout the contaminated areas, could not be inventoried from the aerial data because of the large gamma backgrounds of the other contaminants. From this aerial survey, total isotopic inventories for Area 3 are $0.8 \mathrm{Ci}\left(3.0 \times 10^{10}\right.$ $\mathrm{Bq})$ of ${ }^{60} \mathrm{Co}, 55.4 \mathrm{Ci}\left(2.1 \times 10^{12} \mathrm{~Bq}\right)$ of ${ }^{152} \mathrm{Eu}$, and $3.2 \mathrm{Ci}\left(1.2 \times 10^{11} \mathrm{~Bq}\right)$ of ${ }^{137} \mathrm{Cs}$ in a $5.6-\mathrm{km}^{2}$ area. 
Table 1. Cleanup and treatment methods at the Nerada Teat Shte

\begin{tabular}{|c|c|c|c|c|c|}
\hline Area/event & $\begin{array}{c}\text { Type/extent } \\
\text { of contamination }\end{array}$ & $\begin{array}{c}\text { Terrain/soil } \\
\text { type }\end{array}$ & $\begin{array}{l}\text { Decontamination } \\
\text { method/equipment }\end{array}$ & $\begin{array}{l}\text { Decontamination } \\
\text { results/costs }\end{array}$ & Reference \\
\hline \multicolumn{6}{|l|}{ Area 3} \\
\hline $\begin{array}{l}\text { Unspecified } \\
\text { events }\end{array}$ & ${ }^{239} \mathrm{Pu}$ & $\begin{array}{l}\text { Flat; loose } \\
\text { sandy loam }\end{array}$ & Oil-sealed windrows & Controlled access & Brown et al. 1961 \\
\hline \multirow[t]{2}{*}{ COULOMB C } & $0.5-\mathrm{kt}$ safety experiment & $\begin{array}{l}\text { Smooth, level } \\
\text { land }\end{array}$ & $\begin{array}{l}\text { Scraping with motor- } \\
\text { grader (8-ft blade) to } \\
\text { depth of } 1.5 \text { in.; soil } \\
\text { pushed into windrows }\end{array}$ & FR: $0.20-0.30^{2}$ & Miller 1958 \\
\hline & v & Building roofs & $\begin{array}{l}\text { Fire-hosing } \\
\text { Fire-hosing + detergent }\end{array}$ & $\begin{array}{l}\text { FR: } 0.27-0.34 \\
\text { FR: } 0.24\end{array}$ & Miller 1958 \\
\hline \multicolumn{6}{|l|}{ Area 5} \\
\hline \multicolumn{6}{|l|}{ Area 9} \\
\hline VESTA, JUNO & $\begin{array}{l}{ }^{60} \mathrm{Co},{ }^{157} \mathrm{Eu},{ }^{137} \mathrm{Cs} \text { (VESTA); } \\
24 \text { and } 1.7 \text { ton surface } \\
\text { safety experiments }\end{array}$ & $\begin{array}{l}\text { Loose, sandy } \\
\text { loam; clay-gravel } \\
\text { aggregate }\end{array}$ & $\begin{array}{l}\text { Thin-layer windrowing; } \\
\text { fixation by hot road-oil } \\
\text { spray }\end{array}$ & Controlled access & $\begin{array}{l}\text { Brown } 1961 \\
\text { Fritzsche } 1982\end{array}$ \\
\hline \multicolumn{6}{|l|}{ Area 10} \\
\hline SEDAN & $\begin{array}{l}{ }^{2011} \mathrm{Am},{ }^{60} \mathrm{Co},{ }^{137} \mathrm{Cs}, \\
\mathrm{Rh}\end{array}$ & & $\begin{array}{l}\text { Road decontamination by } \\
\text { high pressure water } \\
\text { spray. Road blader used } \\
\text { to remove thin layer of } \\
\text { contaminated surface } \\
\text { soil from road shoulders; } \\
\text { soil was water sprayed to } \\
\text { prevent resuspension; wet } \\
\text { topsoil windrowed and } \\
\text { fixed with hot road oil. } \\
\text { (Equipment: bladers, } \\
\text { water tank trucks, } \\
\text { road-oil trucks.) }\end{array}$ & & $\begin{array}{l}\text { Brown et al. } 1964 \\
\text { Fritasche } 1982\end{array}$ \\
\hline
\end{tabular}


Table 1 (continued)

\begin{tabular}{|c|c|c|c|c|c|}
\hline Area/event & $\begin{array}{c}\text { Type/extent } \\
\text { of contamination }\end{array}$ & $\begin{array}{l}\text { Terrain/soil } \\
\text { type }\end{array}$ & $\begin{array}{l}\text { Decontamination } \\
\text { method/equipment }\end{array}$ & $\begin{array}{l}\text { Decontamination } \\
\text { results/costs }\end{array}$ & References \\
\hline \multicolumn{6}{|l|}{ Area 11} \\
\hline $\begin{array}{l}\text { Site C } \\
\text { (two } 12 \times 100 \mathrm{~m} \\
\text { plots) }\end{array}$ & ${ }^{239,240} \mathrm{Pu},{ }^{241} \mathrm{Am}$ & $\begin{array}{l}\text { Flat: gravelly } \\
\text { loam }\end{array}$ & $\begin{array}{l}\text { Devegetation, watering } \\
\text { to control dust; } \\
\text { harrowing followed by } \\
\text { vacuuming ( } 12.3-\mathrm{m}^{3} \\
\text { capacity VAC-ALL truck); } \\
\text { soil removed to average } \\
\text { depth of } 6.4 \mathrm{~cm} ; 162 \mathrm{~m}^{3} \\
\text { total soil removed from } \\
2453 \mathrm{~m}^{2} \text { area. }\end{array}$ & $\begin{array}{l}{ }^{241} \mathrm{Am} \text { reduced to } \\
\leqslant 10 \mathrm{pCi} / \mathrm{g}(\leqslant 0.3 \mathrm{~Bq} / \mathrm{g}) \text { of } \\
{ }^{241} \mathrm{Au} \text { in surface soil; } \\
\text { controlled acces site }\end{array}$ & $\begin{array}{l}\text { Essington et al. } 1976 \\
\text { Gilbert } 1977 \\
\text { Dunaway and Sorom } 1982 \\
\text { Orcutt } 1982 \\
\text { Clark } 1983\end{array}$ \\
\hline \multicolumn{6}{|l|}{ Area 13} \\
\hline $\begin{array}{l}\text { Eleven } 50 \times 100 \mathrm{ft} \\
\text { test plots }\end{array}$ & $\begin{array}{l}46 \mathrm{Ci}^{239.240} \mathrm{Pu} \text { in } \\
4,017,000 \mathrm{~m}^{2} \\
62.1-90.5 \mathrm{Ci}^{230.240} \mathrm{Pu} \\
9.6 \mathrm{Ci}^{234} \mathrm{Am}\end{array}$ & $\begin{array}{l}\text { Flat; gravelly, } \\
\text { sandy loam }\end{array}$ & $\begin{array}{l}\text { Plowing } \\
\text { Oiling and scraping } \\
\text { 0.3-in. water leaching } \\
\text { and scraping } \\
\text { 0.3-in. water } \mathrm{FeCl}_{3} \\
\text { leaching } \\
\text { Disking } \\
\text { 1.0-in. water leaching } \\
\text { Scraping } \\
\text { Oiling (RC-0 road oil) } \\
\text { 0.3-in. water leaching } \\
0.3 \text {-in. water-Alconox } \\
\text { leaching } \\
\text { Controlled access site }\end{array}$ & $\begin{array}{l}97.9^{b} \\
95.6 \\
92.7 \\
91.6 \\
\\
89.2 \\
87.4 \\
86.0 \\
69.4 \\
55.0 \\
18.7\end{array}$ & $\begin{array}{l}\text { Gilbert 1977, } \\
\text { Dick and Baker 1967, } \\
\text { Pinson et al. 1957, } \\
\text { Baker et al. 1958, } \\
\text { Brown et al. 1961 }\end{array}$ \\
\hline Hard surfaces & ${ }^{239} \mathrm{Pu}$ & $\begin{array}{l}\text { Concrete; highway } \\
\text { asphalt; wood pads }\end{array}$ & $\begin{array}{l}\text { Sandblasting } \\
\text { Water-detergent scrubbing } \\
\text { Water-detergent hosing } \\
\text { Water hosing } \\
\text { Water scrubbing } \\
\text { Steam cleaning } \\
\text { Vacuum }\end{array}$ & $\begin{array}{l}98.83 \\
98.84 \\
98.61 \\
96.12 \\
94.59 \\
87.80 \\
66.40\end{array}$ & Fritzache 1979 \\
\hline
\end{tabular}


Table 1 (continued)

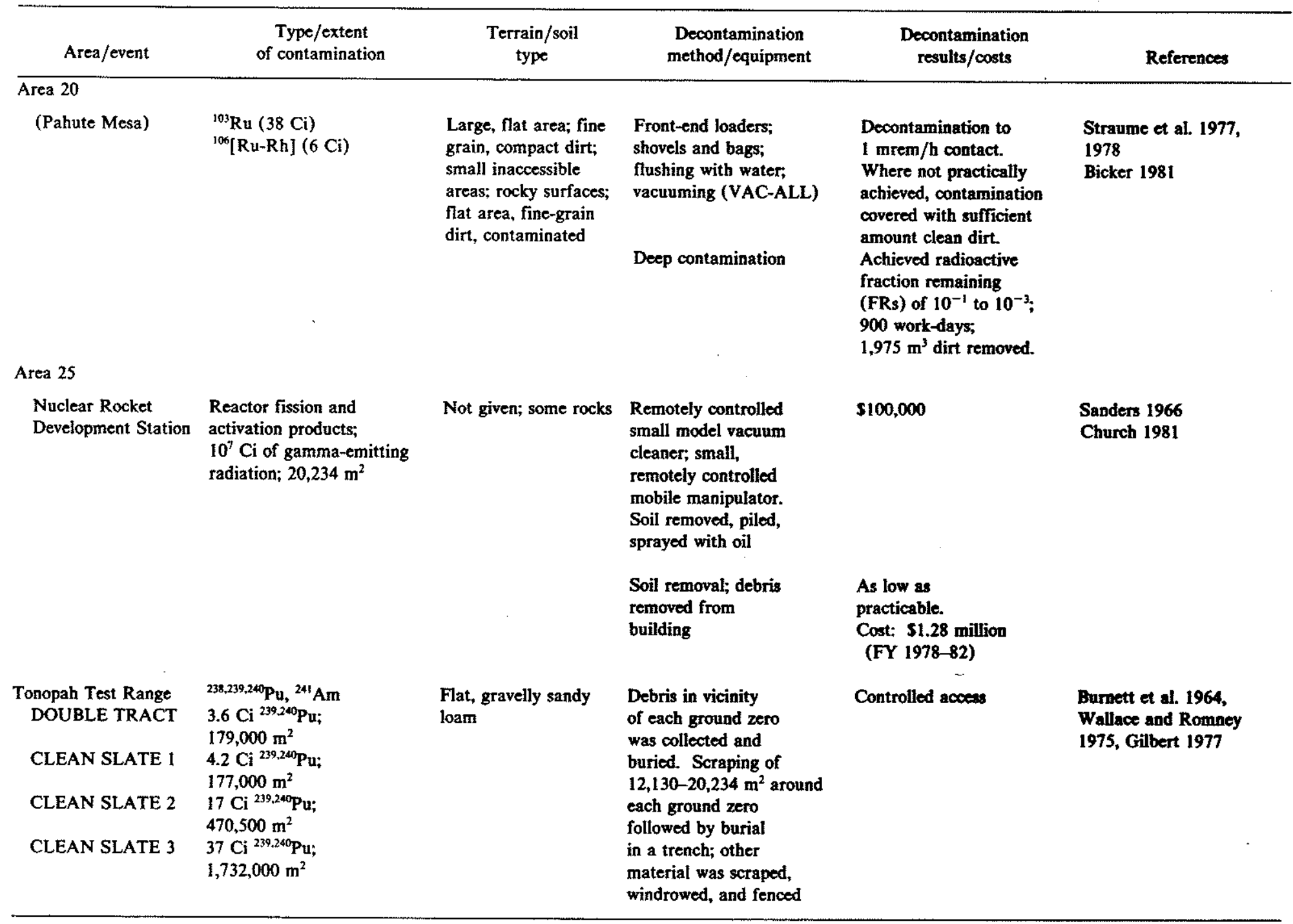

${ }^{\mathrm{s}}$ Fraction of radioactivity remaining.

"Decontamination efficiency (\%). 


\subsubsection{Area 5}

The SMALL BOY event was a low-yield nuclear detonation that took place on July 14, 1962. The device was located slightly above ground and within 150 and $250 \mathrm{ft}(45.2$ and $76.2 \mathrm{~m}$ ) of bunkers in which experiments had been set up (Rarrick 1972). Because the bunkers were within fireball radius, the entire area was covered with fused silica containing fission products. Recovery operations were started one month after the event. Radiation levels at the rear bunker were $\sim 12 \mathrm{R} / \mathrm{h}$ and at the forward bunker were up to $40 \mathrm{R} / \mathrm{h}$. The immediate area around the bunkers was scraped with a grader and bulldozer, and a water truck was used to settle the dust. Following removal of slag from the bunkers, radiation levels were reduced to $\sim 1 \mathrm{R} / \mathrm{h}$.

Information on cleanup activities at the GMX area, which is being considered for cleanup, was not located. The GMX area is within Area 5 and was exposed to a safety shot. Gilbert (1977) estimates an inventory of $1.5 \mathrm{Ci}$ of ${ }^{239,240} \mathrm{Pu}\left(5.6 \times 10^{10} \mathrm{~Bq}\right)$ in the top $5 \mathrm{~cm}$ of soil in a $125.3-\mathrm{km}^{2}$ area. The soil in this area is gravelly, sandy loam.

\subsubsection{Area 9}

Kordas and Anspaugh (1982) list 22 events in Area 9;14 of these were surface or above-ground shots. From aerial surveys, Fritzsche (1982) identified four major contaminated areas in the vicinity of events (1) WILSON, LASSEN, WHEELER, HOOD, OWENS, CHARLESTON, MORGAN, and RUSHMORE (balloon shots at the same or nearby sites); (2) GANNYMEADE; (3) VESTA; and (4) a waste dump. Radioisotopes identified in the surface soil at these sites include ${ }^{60} \mathrm{Co},{ }^{152} \mathrm{Eu}$, and ${ }^{132} \mathrm{Cs}$. As mentioned previously, the low-energy $(60 \mathrm{keV})$ gammas from ${ }^{241} \mathrm{Am}$ appeared to be lost in the large gamma backgrounds from the other contaminants when aerial gamma radiation surveys were taken.

VESTA and JUNO were two surface safety experiments fired in surface structures (U.S. Department of Energy 1983). Only minor levels of radiation were detected following the JUNO event. According to Brown et al. (1961), the area around JUNO and VESTA was bladed; the top soil was pushed into windrows and fixed with hot road-oil spray. The events took place in 1958; the cleanup was undertaken by REECo in 1960. Cursory monthly inspections between 1960 and 1961 indicated that the oil seal in the windrows was satisfactory and did not need repair. Both loose, sandy loam and clay-gravel aggregate are typical soil types in Area 9.

\subsubsection{Area 10}

In Area 10 information was available for only the SEDAN event that took place on July 6 , 1962; the 106-kt detonation resulted in a crater (Kordas and Anspaugh 1982). According to an aerial survey, the principal contaminants are ${ }^{241} \mathrm{Am},{ }^{60} \mathrm{Co},{ }^{137} \mathrm{Cs}$, and ${ }^{102} \mathrm{Rh}$ (Fritzsche 1982).

Wallace and Romney (1975) quote the following from a REECo report by Brown et al. (1964):

Following the SEDAN experiment, after decontamination of the road, a road blader was used to remove a thin layer of surface contaminated soil from the road shoulders. The blading operations progressed from the surfaced road edges toward the open fields on either side. To prevent resuspension of the dust and finely divided contaminant, a water truck was used to wet the surface ahead of the blading operation. The wet topsoil was accumulated into windrows, two feet high and three feet wide. The windrows were then sprayed with hot road oil to confine the contamination. Windrowing operations to confine and control contamination are quite straightforward. Only conventional road maintenance equipment-bladers, water tank trucks, and road-oil trucks-is required. 


\subsubsection{Area 11}

A series of four nuclear safety shots was conducted in the "Plutonium Valley" portion of Area 11 as part of Project 56 (Kordas and Anspaugh 1982; Clark 1983). The tests were conducted on November 1, 3, and 5, 1955, and January 18, 1956, at Sites A, B, C, and D, respectively. Sites B, $\mathrm{C}$, and D are contaminated with ${ }^{241} \mathrm{Am}$ and ${ }^{239,240} \mathrm{Pu}$; Site $\mathrm{A}$ contains ${ }^{235} \mathrm{U}$, and Site $\mathrm{D}$ also contains ${ }^{137} \mathrm{Cs}$. Very little excess radiation is present at blast Site A. Gilbert (1977) estimates an inventory of $36 \mathrm{Ci}\left(1.3 \times 10^{12} \mathrm{~Bq}\right)$ of ${ }^{239,240} \mathrm{Pu}$ in the top $5 \mathrm{~cm}$ of soil in a $0.097-\mathrm{km}^{2}$ area encompassing Sites B, C, and D. The estimate is based on data obtained during a FIDLER (ground-based) survey. Clark (1983) indicates that values from aerial surveys tend to be three times higher than the corresponding ground-based measurements. He reports an inventory of $240 \mathrm{Ci}\left(8.9 \times 10^{12} \mathrm{~Bq}\right)$ of ${ }^{239,240} \mathrm{Pu}$ and $12 \mathrm{Ci}\left(4.4 \times 10^{11} \mathrm{~Bq}\right)$ of ${ }^{241} \mathrm{Am}$ in a $6.03 \mathrm{~km}^{2}$ area. Only the ${ }^{241} \mathrm{Am}$ soil concentration was measured in the aerial survey. The values reported for ${ }^{239,240} \mathrm{Pu}$ are calculated from the plutonium to americium ratio (5.8) reported as a result of earlier soil sample studies.

In 1981 a cleanup and treatment test was conducted near Site C by REECo (Dunaway and Sorom 1982; Orcutt 1982; Clark 1983). The vacuum method of soil removal was tested to see if sufficient amounts of radioactivity could be removed at low costs and with minimum environmental damage. A 20-year-old Central Engineering Co. VAC-ALL model E5-16 vacuum truck was used as the soil collection unit. Pretest surface soil analyses indicated that ${ }^{241} \mathrm{Am}$ concentrations in this area ranged from 7 to $166 \mathrm{pCi} / \mathrm{g}$ (259 to $6142 \mathrm{~Bq} / \mathrm{kg}$ ) (Orcutt 1982).

Two experimental plots, each $12 \times 102 \mathrm{~m}$, were laid out near Site C. Vegetation was cleared from the plots. Soil was first loosened with a harrow and then moistened before vacuuming. The VAC-ALL removed 2.5 in. $(6.4 \mathrm{~cm})$ of top soil from each of the test plots. An estimated $5720 \mathrm{ft}^{3}$ $\left(162 \mathrm{~m}^{3}\right)$ of contaminated soil was deposited in a nearby area and later removed to a waste disposal site. The EG\&G IMP system, a tracked vehicle with an on-board electronic counting system and an intrinsic germanium detector extended away from the body of the vehicle by a boom, was used to make in situ measurements of the degree of ${ }^{241}$ Am decontamination and to identify any remaining areas of localized contamination. Equipment malfunctions, the necessity to revacuum some areas, and problems with rough terrain are discussed by Orcutt (1982). The test plots were decontaminated to $<10 \mathrm{pCi} / \mathrm{g}(<370 \mathrm{~Bq} / \mathrm{kg})$ of ${ }^{241} \mathrm{Am}$ in surface soil.

Problems may arise in the cleanup of this area. Although soil profile analyses indicate that most of the americium and plutonium activity is associated with the top $5.0 \mathrm{~cm}$ of soil, contamination is deeper in washes and mounds (Orcutt 1982). Essington et al. (1976) also indicate that for some locations in Area 11, substantial amounts of plutonium are found below the 5-cm level.

\subsubsection{Area 13}

Field decontamination experiments were first conducted by Test Group 57 at the NTS following a one-point chemical detonation (plutonium oxide dispersion) near Groom Lake, Nevada (Pinson et al. 1957; Baker et al. 1958; Dick and Baker 1967). The detonation resulted in contamination of the immediately surrounding desert soil and vegetation with plutonium and americium. In the studies described by Dick and Baker (1967), eleven $50 \times 100 \mathrm{ft}(15.2$ by $30.5 \mathrm{~m})$ test plots were established in the fallout area $\sim 1,000 \mathrm{ft}(305 \mathrm{~m})$ downwind from ground zero. Methods of soil decontamination or fixation included oiling, spraying with fire-fighting foam, wetting, flooding, wetting with leaching agents and stablizing agents $\left(\mathrm{FeCl}_{3}\right)$, disking, plowing, and scraping. 
Treatment plots were not duplicated. Equipment included a single-bottom farm plow, a disk harrow, a 1000 -gal $\left(3.8-\mathrm{m}^{3}\right)$ water-sprinkling truck, an $850-\mathrm{gal}\left(3.2-\mathrm{m}^{3}\right)$ oil-distribution truck, and a U.S. Army roadgrader. The effectiveness of the decontamination methods was determined by measuring the air concentration of plutonium particles resuspended from the land surface before and after treatment. Resuspension was accomplished by driving a truck back and forth through the area. Decontamination efficiencies are listed in Table 1.

Plowing, oiling, and scraping were found to be the most effective methods of removing plutonium contamination from the land surface (Dick and Baker 1967). Plowing was most effective when the land surface was first moistened to keep surface dust from becoming suspended and then settling back on the plowed areas. Plowing was done to a depth of 12 in. $(0.3 \mathrm{~m})$. The top 2 in. $(5 \mathrm{~cm})$ of soil was scraped and hauled away for burial. Following the cleanup tests, the area was fenced off and has been monitored since that time.

Wallace and Romney $(1975,1977)$ inspected these test plots 17 years later with the purpose of evaluating vegetation recovery and comparing soil surface conditions. The plowed and scraped areas had recovered well with an estimated $25 \%$ of vegetation compared with adjacent nondisturbed areas. The area treated with road oil appeared to be no different from nontreated areas except for the residue of oil remaining. Wallace and Romney suggest that "... plowing might be an effective procedure for any additional decontamination needed at the Area 13 site, especially if road oil or another suitable agent were used after plowing to stablize the soil to prevent a dust bowl." They felt that more experimental work is needed to further test this combination of treatments. They also noted that the test group workers failed to document whether or not the original shrubs survived the treatments.

Hard surfaces, including concrete, asphalt, plate steel, aluminum, galvanized roofing, tar-paper roofing, painted and unpainted wood, glass, brick, stucco, and wood and asbestos shingles set up prior to the shot were also decontaminated by Test Group 57 (Pinson et al. 1957). In addition to the water distribution truck used in land decontamination, equipment included two "Tornado" vacuum cleaners, a steam jenny, and a sand blaster. Decontamination efficiencies are listed by method in Table 1. In separate tests, large highway asphalt, concrete, and wood float pads were decontaminated by the water-detergent hosing method. The efficiency of decontamination was $95.6 \%$ for the highway asphalt and $86.1 \%$ for the wood-float concrete.

Based on a FIDLER survey, Gilbert (1977) estimates an inventory of ${ }^{239,240} \mathrm{Pu}$ in the surface soil $\left(0\right.$ to $5 \mathrm{~cm}$ depth) of $46 \mathrm{Ci}\left(1.7 \times 10^{12} \mathrm{~Bq}\right)$ covering a $4,017,000 \mathrm{~m}^{2}$ area at this site. An aerial survey by Fritzsche (1979) resulted in an estimated inventory of $9.6 \mathrm{Ci}\left(3.6 \times 10^{11} \mathrm{~Bq}\right)$ of ${ }^{241} \mathrm{Am}$. Based on a $\mathrm{Pu} / \mathrm{Am}$ ratio of 9.4 , the range of ${ }^{239,240} \mathrm{Pu}$ inventory is 62.1 to $90.5 \mathrm{Ci}$ $\left(2.30 \times 10^{12}\right.$ to $\left.3.3 \times 10^{12} \mathrm{~Bq}\right)$.

Using available summary data and contour or strata maps, Kinnison and Gilbert (1980) estimated the amount of soil removal necessary to decontaminate down to $160 \mathrm{pCi}(5.9 \mathrm{~Bq})$ of ${ }^{239,240} \mathrm{Pu}$, with removal of the top $15 \mathrm{~cm}$ of soil. This estimate is $180,000,000 \mathrm{~kg}$ of soil covering 269 acres $\left(1.07 \mathrm{~km}^{2}\right)$. The authors stress that this is a rough estimate, and more accurate estimates could be obtained by applying Kriging techniques to available soil data. Soil profile studies by Essington et al. (1976) indicate that most of the ${ }^{239,240} \mathrm{Pu}$ in Area 13 is located in the top $5 \mathrm{~cm}$ of soil.

Based on a maximum dose rate of $1.5 \mathrm{rem} /$ year to a "standard man" living at the site, Martin and Bloom (1977) estimated an "acceptable soil concentration" of ${ }^{239,240} \mathrm{Pu}$ for this site to be 
$\sim 2800 \mathrm{pCi} / \mathrm{g}(103.6 \mathrm{~Bq} / \mathrm{g})$ in the surface soil. They obtained the $2800 \mathrm{pCi} / \mathrm{g}(103.6 \mathrm{~Bq} / \mathrm{g})$ limit by using a plutonium transport and dose estimation model developed explicitly for this site. They noted that only the stratum surrounding ground zero (stratum 6) has an average ${ }^{239,240} \mathrm{Pu}$ concentration exceeding $2800 \mathrm{pCi} / \mathrm{g}\left(103.6 \mathrm{~Bq} / \mathrm{g}\right.$ ). Stratum 6 has an area of $\sim 24,000 \mathrm{~m}^{2} \mathrm{~d}$ (Gilbert 1977 ), which is equivalent to -4400 tons $\left(4 \times 10^{6} \mathrm{~kg}\right)$ of soil cut to a $15-\mathrm{cm}$ depth.

\subsubsection{Area 20}

Straume et al. $(1977,1978)$ report on the cleanup of a large area of rugged terrain following a

spill of radioactively contaminated mud. Precleanup surveys indicated that ${ }^{103} \mathrm{Ru}$ and ${ }^{106} \mathrm{Ru} / \mathrm{Rh}$ were the primary nuclides present, with total estimated activity at the time of release of 38 and 6 $\mathrm{Ci}\left(1.41 \times 10^{12}\right.$ and $\left.2.22 \times 10^{11} \mathrm{~Bq}\right)$, respectively. Because of the varied terrain, several decontamination methods were used; the effectiveness of each was assessed by determining the fraction of radioactivity remaining (FR) following cleanup. The most effective methods for each type of terrain are listed in Table 1. Fraction remainings (FRs) of $10^{-1}$ to $10^{-3}$ were achieved.

Decontamination down to $1 \mathrm{mrem} / \mathrm{h}$ at contact was achieved in most areas. Where this rate was not practically achievable by the described decontamination methods, the contamination was covered with sufficient amounts of clean soil to reach the $1 \mathrm{mrem} / \mathrm{h}$ exposure limit. Approximately 900 work-days were expended on this cleanup, and $2584 \mathrm{yd}^{3}\left(1975.6 \mathrm{~m}^{3}\right)$ of contaminated mud were removed and placed in a subsidence crater $\sim 14 \mathrm{~m}$ below the surface ground level.

Some negative aspects to the cleanup methods and equipment need to be noted: the slowness of the vacuuming method and its impracticality in rugged, rocky areas; the slowness of hand shovels and bags and their impracticality where deep penetration has occurred; the possible recontamination by front-end loaders when drivers are unaware of problems with loader-use in rugged terrain; and the resultant deep penetration in gravel areas when flushing is used.

\subsubsection{Nuclear Rocket Development Station (Area 24)}

In 1965 an accident in Test Cell C at the Nuclear Rocket Development Station resulted in the contamination of approximately 5 acres $\left(20,234 \mathrm{~m}^{2}\right)$ of land with reactor fission and activation products (Sanders 1966, cited in Wallace and Romney 1975). About $10^{7} \mathrm{Ci}\left(3.7 \times 10^{17} \mathrm{~Bq}\right.$ ) of gamma-emitting radiation was released in the incident and about two months were required for decontamination of the land and buildings. Because of the buildings involved and the rocky terrain, large equipment was unsatisfactory for this type of cleanup operation. A small model vacuum cleaner and a small, remotely controlled mobile manipulator were used. Fuel pieces were picked up with tongs. Several inches of soil were removed from around the buildings, and oil was sprayed on piled soil to decrease wind suspension. The total cost of decontamination at this time was about $\$ 100,000$.

An aerial survey performed in 1976 indicated that the major radionuclides present in Area 25 are ${ }^{60} \mathrm{Co}$ and ${ }^{137} \mathrm{Cs}$ (Tipton 1979). These radionuclides are present around several test cells and a waste dump. The most heavily contaminated area is a radioactive materials storage facility, which lies about $2 \mathrm{~km}$ southwest of Test Cell C. The data are presented as gamma exposure rate isopleths $(\mu \mathrm{R} / \mathrm{h})$.

From 1974 to 1983 the REECo performed a radiological survey and cleanup of Area 25 (McKnight et al. 1984). Buildings and land area were decontaminated at a total cost of $\$ 1.6$ 
million. Approximately $350,000 \mathrm{ft}^{3}\left(9910.9 \mathrm{~m}^{3}\right)$ of radioactive material-debris from buildings and land area and scraped soil-was removed for burial in radioactive waste management sites at the NTS. Methods of soil removal are not discussed; front end loaders and road blading machinery were used to remove two large piles of fuel element debris. The majority of Area 25 facilities and land areas have been returned to unrestricted use. The Area remains under Department of Energy control.

\subsubsection{Tonopah Test Range}

Four safety shot areas-DOUBLE TRACK and CLEAN SLATES 1, 2, and 3-on the Tonopah Test Range adjacent to the NTS are being considered for cleanup treatment. At each site a chemical explosive was detonated in close proximity to an assembly of plutonium and/or uranium (Jobst 1979, Rarrick 1972). Detonations 2 and 3 were bunker shots. Detonation dates were May 15, 25, 31, and June 6, 1963, for DOUBLE TRACK and CLEAN SLATES 1, 2, and 3, respectively. DOUBLE TRACK is $-8 \mathrm{~km}$ west of the Tonopah Test Range. The detonations yielded molten plutonium metal that combined with device materials, earth, concrete, and metal. Ground zero and most of the resultant fallout patterns are enclosed by a barbed wire fence with prominent radiation hazard warning signs.

No land decontamination experiments were reported, but the usual post-shot cleanup activities took place (Burnett et al. 1964; Rarrick 1972). Metal and concrete debris in the vicinity of each ground zero and fragments out to a range of $2500 \mathrm{ft}(762 \mathrm{~m})$ were collected and buried in a pit inside the fenced ground zero area. The contaminated surface around each ground zero and areas contaminated by jetting were scraped to a depth of several inches. The soil was placed in the pit or mounded, covered with dirt, compacted, and watered. Windrows were still intact 11 years later (Wallace and Romney 1975). Some areas had been bladed free of vegetation for use as balloon launching sites. The vegetation had partially recovered.

Both ground-based or FIDLER (Gilbert et al. 1975; Gilbert 1977; Kinnison and Gilbert 1980) and aerial (Jobst 1979) radiological surveys of the shot sites have been taken. While there is qualitative agreement between the FIDLER and aerial survey maps, some discrepancies, perhaps because of redistribution during the intervening years, are noted by Jobst (1979). Readily measurable concentrations of ${ }^{241} \mathrm{Am}$ were found outside the barbed wire fence. Some movement of plutonium, americium, and uranium into the soil has occurred at these sites (Essington et al. 1976). In soil profiles collected from CLEAN SLATES 1 and 2 and DOUBLE TRACK, a sizable fraction of the plutonium is found between 5 and $25 \mathrm{~cm}$ below the surface. Gilbert (1977) published estimates of inventories of ${ }^{239,240} \mathrm{Pu}$ in the top $5 \mathrm{~cm}$ of soil at the four sites. These are listed in Table 1.

Kinnison and Gilbert (1980) give rough estimates of the amount of soil that must be removed in order to decontaminate the surface soil down to $160 \mathrm{pCi} / \mathrm{g}\left(5.9 \mathrm{~Bq} / \mathrm{g}\right.$ ) of ${ }^{239,240} \mathrm{Pu}$ (the only level for which there was sufficient data on which to base their estimates). Soil removal down to a depth of $15 \mathrm{~cm}$ was assumed, that being the typical minimum level achievable by heavy earth moving equipment. Soil volume was calculated by multiplying the area of land estimated to be $>160 \mathrm{pCi} / \mathrm{g}$ by an average cleanup depth of $15 \mathrm{~cm}$. Soil weight was calculated by multiplying this soil volume by the average density for the study site. Table 2 summarizes the area and weight results based on the ${ }^{239,240} \mathrm{Pu}$ data. The weight of soil involved is approximately 338,000 tons $\left(3.07 \times 10^{8} \mathrm{~kg}\right)$. 
Table 2. Rough estimates of the amount of soil removal necessary to decontaminate a $15-\mathrm{cm}$ depth of soil down to $160 \mathrm{pCi}$ of ${ }^{239,240} \mathrm{Pu} / \mathrm{g}$

\begin{tabular}{lrcr}
\hline \multicolumn{1}{c}{ Site } & Area $\left(\mathrm{m}^{2}\right)$ & Volume $\left(\mathrm{m}^{3}\right)$ & \multicolumn{1}{c}{ Soil $(\mathrm{kg})$} \\
\hline DOUBLE TRACK & 62,000 & 9,200 & $10,000,000$ \\
CLEAN SLATE 1 & 177,000 & 27,000 & $24,000,000$ \\
CLEAN SLATE 2 & 236,000 & 36,000 & $33,000,000$ \\
CLEAN SLATE 3 & $1,730,000$ & 260,000 & $240,000,000$ \\
Total & $2,205,000$ & 332,000 & $307,000,000$ \\
\hline
\end{tabular}

Source: Adapted with permission from R.R. Kinnison and R.O. Gilbert, Estimates of Soil Removal for Cleanup of Transuranics at NAEG Offsite Safety-Shot Sites, PNL-SA-8267, Pacific Northwest Laboratory, Richland, Wash., 1980.

\subsubsection{Waste Consolidation Program}

Where future use of contaminated land was indicated, surface debris was removed to a waste dump (Brown et al. 1964). The soil was wet down by a water truck, and the top few inches were scraped into windrows by a standard road grader. The moist, windrowed soil was then removed by a large earth mover boosted by D-8 Caterpiliar tractors. The removed soil was mounded into soil dumps that were sprayed with a heavy application of road oil. The debris sites were fenced and posted with appropriate radiation warning signs.

In 1979, REECo began a Radioactive Waste Consolidation Program at NTS (Reynolds Electrical \& Engineering Co., Inc., 1980, 1983). Original plans called for 25 sites to be cleaned over a period of 10 years. By the end of FY 1984, 16 sites in Areas 1 through 7, 9, and 16 had been cleaned. Procedures involved precleanup inspections; establishment of requirements for equipment, personnel, and radiological control; pre- and post-cleanup radiation surveys; and preand post-cleanup soil sample analyses. Debris was moved by dump truck to a radioactive waste management site. At some sites $1 \mathrm{ft}(0.3 \mathrm{~m})$ of soil was removed by bulldozers, front-end loaders, or hand excavation. A road grader was used to clean access roads. Complete wetting with water and mixing of the soil during excavating and loading were maintained. Trenches were backfilled with clean soil.

\subsection{CLEANUP AT OTHER SITES}

\subsubsection{Enewetak Atoll}

Detonation of 43 nuclear devices took place on Enewetak Atoll between 1946 and 1958. Because there was a desire for the Enewetak people to reestablish their villages in some areas, decontamination of some of the islands has taken place. In 1972 and early 1973, the Atomic Energy Commission made a radiological survey of the atoll (Defense Nuclear Agency 1975). The northeast islands of Runit (Yvonne), Enjebi (Janet), Aomon (Saliy), and Eleleron (Ruby) were the most heavily contaminated. Radioactivity was found in the soil, sediment of the lagoon, shrubs and trees, birds, and fish. Cleanup methods tested and results for Yvonne island are summarized in Table 3. Soil was also excised from the surface of Sally, Pearl, Janet, and lrene islands (Barnes and Giacomini 1982). 
Table 3. Cleanup methods at other sites

\begin{tabular}{|c|c|c|c|c|}
\hline Site & $\begin{array}{c}\text { Type of } \\
\text { contamination }\end{array}$ & Decontamination method & Results & References \\
\hline \multicolumn{5}{|l|}{ Enewetak Atoll } \\
\hline \multirow[t]{2}{*}{$\begin{array}{l}\text { Soil Removal Pilot Project: } \\
\text { Sally (KICKAPOO Event) }\end{array}$} & & Removal of vegetation & $\begin{array}{l}\text { Bucket loader superior to bulldozer } \\
\text { superior to road grader }\end{array}$ & Friesen 1982 \\
\hline & . & Soil removal & $\begin{array}{l}\text { Bulldozer most rapid equipment } \\
\text { for making windrows; bucket } \\
\text { loader used to load windrowed } \\
\text { soil into dump trucks }\end{array}$ & Friesen 1982 \\
\hline $\begin{array}{l}\text { Plowing experiment: Janet } \\
25 \times 25 \text { m plots }\end{array}$ & & Plowing to $50 \mathrm{~cm}$ & $\begin{array}{l}\text { Effective in mixing }{ }^{241} \text { Am at surface } \\
\text { down to } 50 \mathrm{~cm} \text {; "hot spots" remained; } \\
\text { suggested a follow-up of disking }\end{array}$ & Dunaway 1982 \\
\hline Soil removal: Yvonne & $\begin{array}{l}{ }^{239.240} \mathrm{Pu} \\
{ }^{241} \mathrm{Am},{ }^{60} \mathrm{Co} \\
{ }^{155} \mathrm{Eu},{ }^{137} \mathrm{Cs}\end{array}$ & $\begin{array}{l}\text { Top } 20 \mathrm{~cm} \text { soil removed, } \\
\left(8,200 \mathrm{~m}^{3}\right) \text {, burial in crator, } \\
\text { concrete capped. Follow-up } \\
\text { of backblading and coverage } \\
\text { with clean soil }\end{array}$ & $\begin{array}{l}\text { The island is currently quaran- } \\
\text { tined. The transuranics average } \\
\text { radioactivity is } 7.8 \mathrm{pCi} / \mathrm{g}(0.27 \mathrm{~Bq} / \mathrm{g}) \\
\text { for southern YVONNE and } 41 \mathrm{pCi} / \mathrm{g} \\
(1.52 \mathrm{~Bq} / \mathrm{g}) \text { for northern YVONNE }\end{array}$ & $\begin{array}{l}\text { Barnes and Giacomini } \\
1982 \\
\text { Tipton et al. } 1981\end{array}$ \\
\hline \multicolumn{5}{|l|}{ Carlsbad, New Mexico } \\
\hline Project GNOME & ${ }^{3} \mathrm{H},{ }^{90} \mathrm{Sr}$ & $\begin{array}{l}\text { Debris, soil removal; } \\
\text { disposal into cavity, } \\
\text { trenches }\end{array}$ & $\begin{array}{l}\text { Final cleanup status-unrestricted use } \\
\text { use on the surface, subsurface } \\
\text { drilling is restricted. Some areas } \\
\text { fenced; follow-up surveys }\end{array}$ & $\begin{array}{l}\text { Wallace and Rommey } \\
1975 \\
\text { Bicker } 1981\end{array}$ \\
\hline \multirow[t]{2}{*}{ Tatum Dome, Mississippi } & $\begin{array}{l}{ }^{125} \mathrm{Sb} \text { and other } \\
\text { radionuclides }\end{array}$ & $\begin{array}{l}\text { Soil excavation with front- } \\
\text { end loaders, backhoes, } \\
\text { draglines, trucks }\end{array}$ & $\begin{array}{l}\text { Removal of }>8410 \mathrm{~m}^{3} \text { soil; } \\
\text { deposition into cavity or transport } \\
\text { to NTS. Manual handling of } \\
\text { large debris, clay }\end{array}$ & Bicker 1981 \\
\hline & & & $\begin{array}{l}\text { Cost: } \$ 1,080,000 \\
\left(\$ 40 / \mathrm{yd}^{3} \text { or } \$ 30.5 / \mathrm{m}^{3}\right.\end{array}$ & Church 1974 \\
\hline
\end{tabular}


Table 3 (continued)

\begin{tabular}{|c|c|c|c|c|}
\hline Site & $\begin{array}{c}\text { Type of } \\
\text { contamination }\end{array}$ & Decontamination method & Results & References \\
\hline \multicolumn{5}{|l|}{ Los Alamos, New Mexico } \\
\hline Main Technical Area & $\begin{array}{l}\text { Primarily } \\
{ }^{239} \mathrm{Pu}\end{array}$ & $\begin{array}{l}\text { Soil removal. Soil loosened } \\
\text { with ripper on back of crawler. } \\
\text { tractor; soil removed with front- } \\
\text { end loaders; loaded into } \\
\text { plastic-lined dump trucks. } \\
\text { Garden hose used for water } \\
\text { spray. Small spots: hand } \\
\text { shovel and plastic bags }\end{array}$ & $\begin{array}{l}\text { As low as reasonably } \\
\text { achievable: approx. } 16 \text { hectares } \\
(40 \text { acres) at cost of } \$ 769,000 \text {. } \\
15,000 \mathrm{~m}^{3} \text { of material removed }\end{array}$ & Ahlquist 1977,1981 \\
\hline Wasteline-townsite & $\begin{array}{l}\text { Primarily } \\
{ }^{239} \mathrm{Pu}\end{array}$ & $\begin{array}{l}\text { Removal of contaminated } \\
\text { industrial wasteline } \\
\text { with backhoe, plastic } \\
\text { lined dump trucks }\end{array}$ & As low as practical & $\begin{array}{l}\text { Gunderson and } \\
\text { Ahlquist } 1979\end{array}$ \\
\hline Wasteline leak & $\begin{array}{l}\text { Variable radionuclide } \\
\text { content }\end{array}$ & $\begin{array}{l}\text { Soil removal with front- } \\
\text { end loaders, plastic lined } \\
\text { dump trucks }\end{array}$ & $\begin{array}{l}\text { Cost } \$ 100,000 \text { including cleanup/ } \\
\text { repair of wasteline, spill containment, } \\
\text { surveillence, sample analysis, excavation, } \\
\text { restoration, waste disposal }\end{array}$ & Smith et al. 1977 \\
\hline Adjacent area & ${ }^{239} \mathrm{Pu}$ & $\begin{array}{l}\text { Contaminated soil removed } \\
\text { with front-end loader } \\
\text { alone or in conjunction } \\
\text { with a road maintainer and/ } \\
\text { or dozer. Hand excavation } \\
\text { in some areas }\end{array}$ & $\begin{array}{l}\text { Decontaminated down to } \\
\text { less than } 0.06 \mathrm{pCi} / \mathrm{m}^{3} \\
\left(2.2 \times 10^{-3} \mathrm{~Bq} / \mathrm{m}^{3}\right)\end{array}$ & Barker 1982 \\
\hline Accidental release & $\begin{array}{l}\text { Rocky Flats, Colorado, } \\
{ }^{239} \mathrm{Pu}\end{array}$ & $\begin{array}{l}\text { Removal of contaminated } \\
\text { soil and leaking oil drums } \\
\text { Residual activity contained } \\
\text { underneath asphalt and } \\
\text { concrete pads }\end{array}$ & Effective containment & $\begin{array}{l}\text { Wallace and Romney } \\
1975\end{array}$ \\
\hline \multicolumn{5}{|l|}{ Savannah River Plant } \\
\hline Nearby field & ${ }^{238,239,240} \mathrm{Pu}$ & Disking and plowing & $\begin{array}{l}\text { Resulted in little movement } \\
\text { out of } 0-5 \mathrm{~cm} \text { depth }\end{array}$ & Corey et al. 1978 \\
\hline
\end{tabular}




\subsubsection{Nonweapon Detonations}

As part of the Plowshare program a $3 \mathrm{kt}$ nuclear device was detonated in bedded salt rock 30 miles $(4.8 \mathrm{~km}$ ) southeast of Carlsbad, New Mexico (GNOME Site). Radioactive mud and debris were either placed in the shaft or buried. A follow-up radiological survey disclosed that further cleanup was necessary (cleanup methods are summarized in Table 3).

Two nuclear test detection experiments, SALMON and STERLING, were conducted at the Tatum Dome Site near Hattiesburg, Mississippi. Problems encountered during the cleanup are discussed by Bicker (1981). These two sites may be of limited relevance to cleanup at NTS because the terrain, debris, and problems encountered are quite different from those at NTS.

\subsubsection{Accidental Releases}

Industrial processing of radioactive materials and leakage from waste storage sites have resulted in accidental releases. Soil cleanup methods used at these sites are also summarized in Table 3.

\subsubsection{Weapons Accidents}

Two accidents, both involving weapons-bearing B-52 bombers, dispersed plutonium over land areas. At Palomares, Spain, two nuclear weapons chemically detonated, dispersing plutonium over some 1200 acres $\left(4.9 \mathrm{~km}^{2}\right.$ ) of ground (Langham 1968; Jordan 1971). Cleanup methods employed were determined by the radioactivity levels in the contaminated area. All crops were stripped from the fields and destroyed where readings above $0.35 \mu \mathrm{Ci} / \mathrm{m}^{2}\left(13,000 \mathrm{~Bq} / \mathrm{m}^{2}\right)$ were observed. The soils with readings between 0.35 and $35 \mu \mathrm{Ci} / \mathrm{m}^{2}\left(13,000\right.$ and $\left.1,300,000 \mathrm{~Bq} / \mathrm{m}^{2}\right)$ were deep-plowed to at least $10 \mathrm{in} .(0.3 \mathrm{~m})$ deep to reduce the probability of resuspension. Areas with readings greater than $35 \mu \mathrm{g} / \mathrm{m}^{2}$ were stripped of vegetation and topsoil, and the contaminated debris was shipped to the United States. Areas too rough to plow were turned under by hand. Following decontamination, air concentrations in the vicinity were the same as those expected from worldwide fallout of plutonium. Crop uptake was so low that consumption presented no hazard to consumers (Fowler et al. 1968; Buchholtz et al. 1971).

Wallace and Romney (1975) discussed problems subsequent to the plowing program. The plowing brought an excess of soluble salts to the soil surface, with adverse effects on crop production.

The crash of a Strategic Air Command B-52 bomber near Thule Air Force Base in Greenland resulted in contamination of $238 \mathrm{~km}^{2}$ with $3100 \mathrm{~g}$ of plutonium (Langham 1968; Jordan 1971; Wallace and Romney 1975). Road graders were used to windrow the frozen ice and snow. Mechanized loaders were used to place the contaminated material into boxes for shipment to the United States. An area of $\sim 70 \mathrm{~km}^{2}$ was cleared to a depth of 4 in. $(0.1 \mathrm{~m})$.

\subsection{EXPERIMENTAL STUDIES}

Two experimental studies are relevant to the cleanup problem at NTS. The Stoneman II Tests of Reclamation Performance investigated a variety of proposed decontamination procedures, each applicable to a specific simulated level of fallout contamination on various land target surfaces (Lee et al. 1959). A synthetic fallout labeled with ${ }^{140} \mathrm{La}$ was applied to four soil surfaces: (1) moist green grass; (2) moist tilled surface; (3) dry tilled surface; and (4) dry, hard surface with withered vegetation. Decontamination effectiveness was dependent on terrain type. Soil with deep cracks and 
fissures (in which contamination was deeper than the removed surface layer) and soils with noncohesiveness were the most difficult to decontaminate during first pass. On all terrain types used in the experiments, decontamination ratios of $\leqslant 0.01$ were obtained by successive cycle application of the scraper and grader plus scraper reclamation methods.

Experiments on the physical removal of radioactive surface contamination were also conducted at the U.S. Department of Agriculture Agricultural Research Center at Beltsville, Maryland (Menzel and James 1959). In the first part of the experiment, contaminated sod, standing crops, and straw mulch were removed. In the second series, more applicable to NTS, contaminated soil was removed from fields of silt loam and sandy loam. Surfaces were contaminated with ${ }^{140} \mathrm{La}$ or ${ }^{32} \mathrm{P}$. The percentages of decontamination achieved by scraping with a road grader following the various pretreatments are indicated in Table 4. Scraping was done with a road grader with a 7-ft (2.1-m)-wide blade. Over $98 \%$ decontamination was achieved by scraping off $3-4 \mathrm{in}$. $(0.08-0.1 \mathrm{~m})$ of surface soil when the surface was relatively smooth before contamination. The use of asphalt coatings on the soil in conjunction with scraping was of no benefit.

\subsection{EQUIPMENT}

For ground-based in situ measurements of plutonium utilizing the gamma activity of ${ }^{241} \mathrm{Am}$, EG\&G employed IMP vehicles, tracked all-terrain vehicles manufactured by Thiokol Corporation. The monitoring system consists of a high-purity germanium detector mounted on the end of a retractable mast, an amplifier, a 4096-channel analyzer, and a computer for spectrum analyses and data recording (Giacomini and Miller 1981). IMPs were used to monitor cleanup activity at both NTS and Enewetak Atoll.

Cleanup equipment used at each site and manufacturer's name, where available, are listed in Table 5. Barbier (1981) lists existing machinery, used in other industrial operations, that could be used for large-scale outdoor decontamination operations. He lists vacuum trucks made by TYMCO and FMC. Other manufacturers of vacuum equipment are General Resource Corp., Drum Engineering, Inc., The Hayden Co., Super Products, ULTRAVAC-DP Way Corp., Peabody Myers, Vacuum Inductors, The Kleener Kleener Corp., AI Research, Inc., NFE International Ltd., Wm. W. Meyer \& Sons, Inc., Rich Mac Systems, Vacuum Truck Equipment Co., Inc., and Huber Mfg. Co. In addition, earth moving equipment designed for other reclamation projects may be of interest for use at NTS. A $40-\mathrm{ft}(12.2 \mathrm{-m})$ Balderson blade mounted on a Caterpillar D-9 tractor was specifically designed for reclaiming area-mined coal spoil piles (Anonymous 1975). The scraper moves $\sim 6000 \mathrm{yd}^{3} / \mathrm{h}\left(4587 \mathrm{~m}^{3} / \mathrm{h}\right)$. A $24 \mathrm{ft}(7.3 \mathrm{~m})$ wide grading bar that mounts on a Caterpillar D-8 crawler tractor can be used to smooth level 7 acres $/ \mathrm{h}\left(28,328 \mathrm{~m}^{2} / \mathrm{h}\right)$.

\subsection{CHEMICAL AND PHYSICAL METHODS}

As alternative methods to soil removal and/or plowing, several chemical and physical methods for stabilizing, immobilizing, or removing radioactivity from soil have been proposed. With the exception of methods used at NTS, most of these methods have been tested only in the laboratory or on uranium mill tailings, the latter test encompassing smaller areas than those at NTS.

Early experiments at NTS involved the use of road oil on soil to decrease the probability of plutonium resuspension. According to Wallace and Romney (1975), the road-oil treated areas appeared to be no different from nontreated areas 17 years later, except for the remaining oil. 
Table 4. Percentage of decontamination by scraping surface soil following various treatments

\begin{tabular}{|c|c|c|c|c|c|c|c|}
\hline \multirow{3}{*}{$\begin{array}{l}\text { Number of } \\
\text { cuts with } \\
\text { grader }\end{array}$} & \multirow[b]{3}{*}{$\begin{array}{c}\text { Asphalt } \\
\text { spray }\end{array}$} & \multicolumn{6}{|c|}{ Soil preparation } \\
\hline & & \multicolumn{2}{|c|}{ Plowed } & \multicolumn{2}{|c|}{ Disked } & \multicolumn{2}{|c|}{ Seedbed } \\
\hline & & Rolled & $\begin{array}{l}\text { Not } \\
\text { rolled }\end{array}$ & Rolled & $\begin{array}{l}\text { Not } \\
\text { rolled }\end{array}$ & Rolled & $\begin{array}{l}\text { Not } \\
\text { rolled }\end{array}$ \\
\hline \multicolumn{8}{|c|}{ Sassafras sandy loam } \\
\hline 1 & Yes & 75 & 96 & 66 & 70 & 82 & 99 \\
\hline 1 & No & 85 & 68 & 60 & 80 & 62 & 100 \\
\hline 2 & No & 89 & 100 & 95 & 100 & 93 & 100 \\
\hline \multicolumn{8}{|c|}{ Elkton silt loam } \\
\hline 1 & Yes & 91 & 69 & 88 & 89 & 99 & 92 \\
\hline 1 & No & 98 & 84 & 91 & 91 & 94 & 96 \\
\hline 2 & No & 87 & 91 & 100 & 86 & 100 & 100 \\
\hline
\end{tabular}

Source: Reprinted with permission from R. G. Menzel and P. E. James, "Physical Removal of Radioactive Surface Contamination from Agricultural Land," pp. 45-59 in Proceedings of the Thirty-fifth Annual Meeting of the National Joint Committee on Fertilizer Application, National Plant Institute, Washington, D.C., 1959.

Although the oil surface had broken up, in most cases the soil remained stabilized in pieces from $1 / 2$ to 2 in. $(1.3$ to $5.1 \mathrm{~cm})$ in thickness.

In addition to road oil, a number of other substances can be used as fixatives, including asphalt, diesel oil, and MC-70 (Tawil and Bold 1983). Dust control materials include generic products such as calcium chloride, magnesium chloride, and calcium lignosulfonate and proprietary products such as Coherex and Compound SP. Road oil, MC-70, magnesium chloride, and calcium lignosulfonate have been used at NTS. Fixatives and the manufacturer's name, where available, are listed in Table 6. Several of the products have been used, or suggested, for stabilization of uranium mill tailings. Some of the products need to be evaluated in terms of their effects on plants and animals.

Soil decontamination by leaching was tested at NTS by Pinson et al. (1957). Leaching with 1 in. $\left(2.5 \times 10^{-2} \mathrm{~m}\right)$ of water, 0.3 in. $\left(7.6 \times 10^{-3} \mathrm{~m}\right)$ water containing $\mathrm{FeCl}_{3}, 0.3$ in. $(7.6 \times$ $\left.10^{-3} \mathrm{~m}\right)$ of water, and 0.3 in. $\left(7.6 \times 10^{-3} \mathrm{~m}\right)$ of water with Alconox detergent resulted in decontamination efficiencies of $85,84,33$ and $3 \%$, respectively.

Horton and Albenesius (1976) conducted a series of experiments to test the feasibility of separation of plutonium-contaminated soil into plutonium-rich and -depleted fractions. Waterscrubbing and washing of a sample of soil from the Savannah River Plant burial ground separated out a clay-silt fraction containing $\sim 95 \%$ of the plutonium but constituting only one-third of the total soil.

The use of sorting and scrubbing to remove plutonium contamination from soils was reviewed by Stevens et al. (1982), who cite work at Rockwell International that has included wet and dry 
Table 5. Equipment used for cleanup of radloactively contaminated sites

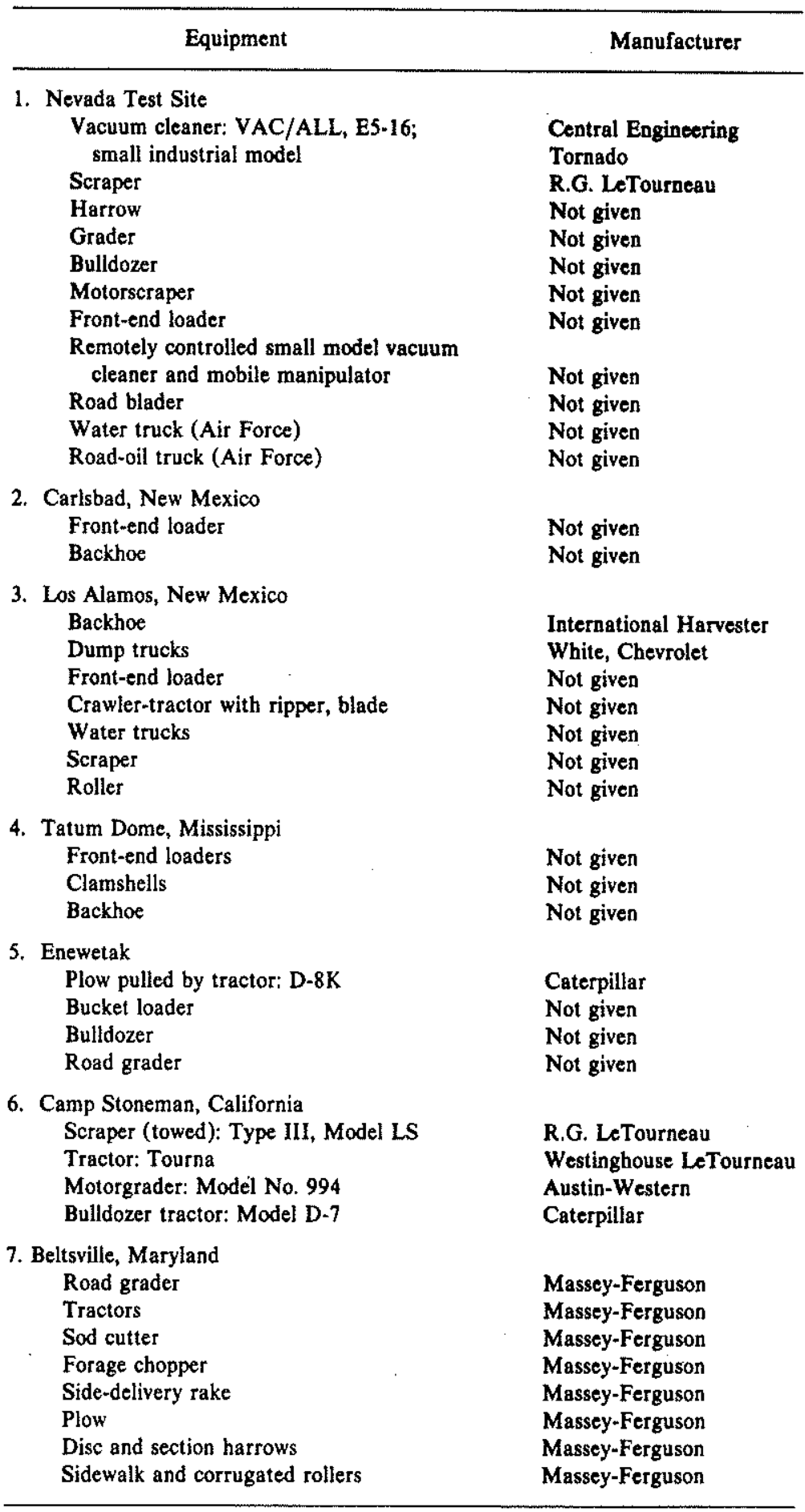


Table 6. Soil stabilizers

\begin{tabular}{|c|c|c|}
\hline Product & Manufacturer & References \\
\hline Road oil (rapid cure) & Not given & $\begin{array}{l}\text { Baker et al. 1958, Dick } \\
\text { and Baker } 1967\end{array}$ \\
\hline Diesel, bunker, and dust oils & Not given & Tawil and Bold 1983 \\
\hline MC (petroleum product) & Not given & Tawil and Bold 1983 \\
\hline Polyurethane foam spray & Dow Chemical Company & $\begin{array}{l}\text { Hornbacher et al. } 1971, \\
\text { Lindsay et al. } 1973\end{array}$ \\
\hline Resins (Geo Tech) & Southwest Consultants & Wallace and Romney 1975 \\
\hline Iron chloride, iron oxide & Master Builders, Columbus, $\mathrm{OH}$ & $\begin{array}{l}\text { Pinson et al. } 1957 \\
\text { Baker et al. } 1958 \text {, Dick } \\
\text { and Baker } 1967 \\
\text { Wallace and Romney } 1975\end{array}$ \\
\hline Krilium (an organic agent) & Monsanto Chemicals Company & Wallace and Romney 1975 \\
\hline Asphalt emulsion & Not given & Hartley et al. 1980 \\
\hline Elastomeric polymer (DCA-70) & Union Carbide & $\begin{array}{l}\text { Havens and Dean } 1969, \\
\text { Wallace and Romney } 1975\end{array}$ \\
\hline $\begin{array}{l}\text { Calcium lignosulfonate } \\
\text { (Norlig A, Lignosite, } \\
\text { Polybinder) }\end{array}$ & $\begin{array}{l}\text { American Can Co., GA } \\
\text { Pacific, IIT-Rainier, } \\
\text { Polychem International, Inc. }\end{array}$ & $\begin{array}{l}\text { Havens and Dean } 1969, \\
\text { Wallace and Romney } 1975, \\
\text { Tawil and Bold } 1983\end{array}$ \\
\hline Calcilox cement & Dravo Corp., Pittsburgh, PA & Martin 1979 \\
\hline $\begin{array}{l}\text { Soil binders (TURCO } 5833 \text {, } \\
\text { PetroSet) }\end{array}$ & Turco Products, Inc., not given & $\begin{array}{l}\text { McKinley and McKinney } \\
1978\end{array}$ \\
\hline Coherex (petroleum resins) & Witco Co. & Tawil and Bold 1983 \\
\hline Compound SP (polymer) & Johnson March, Inc. & Tawil and Bold 1983 \\
\hline Calcium chloride & Dow Chemical Co. & Tawil and Bold 1983 \\
\hline Magnesium chloride & Not given & Tawil and Bold 1983 \\
\hline
\end{tabular}


screening, attrition scrubbing, ultrasonic scrubbing, chemical oxidation, calcination, deliming, flotation, and heavy liquid density separation. They also assessed the effectiveness of three scrub solutions on transuranic-contaminated soils from five Department of Energy sites. Solutions tested included (1) aqueous $\mathrm{NaOH}, \mathrm{pH}$ of 12.5 ; (2) $2 \mathrm{~N} \mathrm{HCl}$; and (3) 2 vol \% of concentrated $\mathrm{HNO}_{3}, 0.2$ vol \% of concentrated HF; 2 vol \% of pine oil and 5 wt \% of Calgon. The success of decontamination, which was by physical and chemical means, depended on the type of soil. All soils showed an enrichment of activity in the fine fraction after scrubbing with the $\mathrm{pH} 12.5$ solution; it did not solubilize the actinide contamination. The $2 \mathrm{~N} \mathrm{HCl}$ reagent solubilized soil constituents, removing contamination that had migrated into mineral surfaces. The third solution solubilized particulate actinide and actinide dispersed on the surface of soil particles.

Lee and Tamura (1981) characterized the physicochemical properties of contaminated soil from Area 20 of NTS in order to evaluate potential decontamination methods. More than $90 \%$ of the total radioactivity was recovered in $25 \%$ of the total sample weight by a grinding-sieving process. Lee and Tamura further suggested that radioactive particles might be removed from the contaminated soil by (1) a controlled vacuum collector, (2) density separation, (3) grinding-sieving separation, or (4) a combination of these techniques based on the density and compressibility differences between radioactive and nonradioactive particles. 


\section{REPRESENTATIVE COSTS OF CLEANUP AND TREATMENT OF CONTAMINATED AREAS}

\subsection{ESTIMATING COSTS PER UNIT OPERATION FOR HAZARDOUS WASTE SITES}

Cleanup consists of initial monitoring to establish the extent and type of contamination, planning and execution of cleanup procedures, disposal of contaminated wastes, stabilization of the site, and monitoring to ascertain the success of the cleanup. One attempt to develop a consistent cost methodology for cleanup is that described by Rishel et al. in a 1982 U.S. Environmental Protection Agency (EPA) report. Although their study was concerned with hazardous waste sites, and not with radioactive site cleanup, it does provide a description of how cost estimation methodologies can be developed. It may be possible, then, to adapt their methods to radioactively contaminated sites such as Nevada Test Site.

To arrive at a cost methodology that would be applicable to any type of hazardous waste cleanup, Rishel et al. 1982 examined such projects at some 35 uncontrolled landfill or impoundment disposal sites across the United States dividing them into comparable components and subcomponents for comparisons between sites, and costing each component separately. This procedure was developed so that costs for other projects could be estimated by identifying the components involved and consulting their cost-per-component data. Component costs for one site in Newark, New Jersey, were calculated, and U.S. upper and lower costs were estimated in order to provide a range of values for comparison. Price lists for labor, materials, transportation, etc. were compiled primarily from the Dodge and Means Guides (McMahon 1979; Robert S. Means Company 1979) for both English and metric units, and regionally adjusted using indices provided in the Dodge Guide. Costs for overhead and contingencies were not included in these total costs but were calculated by summing all the components within a unit operation to obtain a subtotal capital cost. From this subtotal capital costs, an overhead allowance $(25 \%)$ and a contingency allowance (10 to $40 \%$, depending upon the extent to which component requirements can be precisely estimated) were obtained. The subtotal capital cost plus overhead and contingency allowances represent the estimate of total unit operation cost. Tables B.1 through B.7 in Appendix B are taken from the EPA report by Rishel et al. 1982 and show the unit for which costs were estimated, costs per unit, sources of the cost data, U.S. upper and lower average costs per unit, and costs per unit at Newark, New Jersey, for the various components identified by the authors.

\subsection{COSTS FOR SITE STABILIZATION, LONG-TERM CARE, AND WASTE RELOCATION}

As a part of the process of developing information to support the preparation of standards covering decommissioning of nuclear facilities, the Nuclear Regulatory Commission undertook studies on the technology, safety, and costs of decommissioning reference nuclear facilities. One of these studies (Murphy and Holter 1980) involved the conceptual decommissioning of commercial low-level waste burial grounds. Two generic burial grounds, one located on an arid western site and the other on a humid eastern site, were used as reference facilities in the study. The climate, geology, and hydrology of the sites were chosen to be typical of western and eastern sites. Each reference burial ground was assumed to occupy $\sim 70$ ha and included 180 trenches with a total of $1.5 \times 10^{6} \mathrm{~m}^{3}$ of radioactive waste. The basic options considered in the study are site/waste stabilization followed by long-term care of the site and waste relocation. Three plans were evaluated 
for each site: (1) a minimal plan includes site inspection, stabilization of trenches and damaged areas, and vegetation management; (2) a modest plan includes capping, revegetation, and vegetation management; and (3) the complex plan includes a subsurface rock layer with hard top, increased capping thickness, revegetation, and vegetation management. Estimated costs for each plan are found in Table 7. Long-term care for the reference site includes administrative control, environmental surveillance, and site maintenance. Costs for long-term care at an arid western site are estimated in Table 8. Information on costs estimates at a humid eastern site is included in the report by Murphy and Holter (1980). Waste relocation involves exhumation of the buried waste, repackaging the waste if necessary, and reburial of the waste at a deep geologic disposal site in a shallow-land burial ground, or in another trench on the same site. Cost estimates for waste relocation are found in Table 9.

Table 7. Estimated costs of site stabilization (arid western site)

\begin{tabular}{|c|c|c|c|}
\hline \multirow[b]{2}{*}{ Cost category } & \multicolumn{3}{|c|}{$\begin{array}{l}\text { Cost of plan } \\
\text { ( } \$ \text { millions })\end{array}$} \\
\hline & Minimal & Modest & Complex \\
\hline \multicolumn{4}{|l|}{ Manpower } \\
\hline Support staff & 0.298 & 0.704 & 0.770 \\
\hline Decommissioning workers & 0.066 & 0.360 & 0.859 \\
\hline Contractor's equipment & 0.035 & 0.374 & 0.870 \\
\hline Material and expendable equipment & 0.071 & 0.905 & 4.558 \\
\hline Contractor's fee ${ }^{c}$ & & 0.188 & 0.565 \\
\hline $\begin{array}{l}\text { Miscellaneous owner } \\
\text { expense }^{d}\end{array}$ & 0.008 & 0.018 & 0.020 \\
\hline Environmental monitoring & 0.008 & 0.023 & 0.028 \\
\hline Records maintenance & 0.001 & 0.006 & 0.006 \\
\hline Total (rounded) & 0.5 & 2.6 & 7.7 \\
\hline
\end{tabular}

${ }^{a}$ Number of figures shown is for computational accuracy only and does not imply precision to the nearest thousand dollars.

${ }^{\mathrm{b}}$ Costs include $25 \%$ contingency.

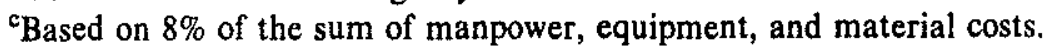

${ }^{d}$ Includes utilities, insurance, and taxes.

Source: Murphy, E. S. and G. M. Holter, Technology, Safety and Costs of Decommissioning a Reference Low-Level Waste Burial Ground. NUREG/CR-0570, Vol. 1, Pacific Northwest Laboratory, Richland, Wash., 1980. 
Table 8. Summary of estimated long-term care costs

\begin{tabular}{|c|c|c|c|c|c|c|c|}
\hline \multirow{3}{*}{$\begin{array}{l}\text { Stabilization } \\
\text { plan preceding } \\
\text { long-term care }\end{array}$} & \multicolumn{6}{|c|}{$\begin{array}{l}\text { Costs for time period }{ }^{\mathrm{a}, \mathrm{b}} \\
\text { (millions of constant } 1978 \text { dollars) }\end{array}$} & \multirow{3}{*}{$\begin{array}{l}\text { Total costs for } \\
200 \text { Years } \\
\text { (in millions } \\
\text { of constant } \\
1978 \text { dollars) }\end{array}$} \\
\hline & \multicolumn{2}{|c|}{$\begin{array}{c}0-5 \text { Years } \\
\text { after } \\
\text { stabilization }\end{array}$} & \multicolumn{2}{|c|}{$\begin{array}{c}\text { 6-25 Years } \\
\text { after } \\
\text { stabilization }\end{array}$} & \multicolumn{2}{|c|}{$\begin{array}{c}\text { 26-200 Years } \\
\text { after } \\
\text { stabilization }\end{array}$} & \\
\hline & Annual & Total & Annual & Total & Annual & Total & \\
\hline $\begin{array}{l}\text { Minimal and modest } \\
\text { plans for the } \\
\text { western site }\end{array}$ & 0.162 & 0.808 & 0.106 & 2.122 & 0.078 & 13.580 & 16.5 \\
\hline $\begin{array}{l}\text { Complex plan for the } \\
\text { western site }\end{array}$ & 0.230 & 1.150 & 0.100 & 2.000 & 0.072 & 12.512 & 15.7 \\
\hline
\end{tabular}

Source: Murphy, E. S. and G. M. Holter. Technology, Safety and Costs of Decommissioning a Reference Low-Level Waste Burial Ground. NUREG/CR-0570, Vol. 1, Pacific Northwest Laboratory, Richland, Wash. 1980.

\subsection{COSTS FOR STABILIZATION OF FINE-SIZED MINERALS}

The U.S. Bureau of Mines has issued a report (Dean, et al. 1974) on the estimated cost for stabilizing fine-sized mineral wastes at a reference uranium mill tailings site. These wastes represent the most difficult materials to stabilize. The principal methods for stabilization of these wastes include physical covering of the tailings with soil or other restraining materials, the chemical use of a material to interact with fine-sized minerals to form a crust, and the growth of plants in the tailings. Costs of these three methods plus a fourth which involves a combination of chemical reaction and revegetation are presented in Table 10. Note that the publication date for this report is 1974 , and the cost estimates are more than 10 years out of date.

\subsection{COSTS OF FIXATIVES}

A Pacific Northwest Laboratory report (Tawil and Bold 1983) quotes 1983 price estimates for fixatives suitable for use on radioactively contaminated surfaces. The fixatives in Group 1 act by the formation of membrane layers over the surface and those in Group 2 act to bind particles by absorbing into them. Information on these fixatives is contained in Table 11.

Comments on the durability of these various fixatives are as follows:

1. Road oil is durable for 20 years or more.

2. Membranes formed with the MCs break under foot or vehicle traffic.

3. Emulsified asphalt produces reduced penetrating power compared with MCs and tends to ball up with vehicle traffic.

4. The first application of Coherex is durable for 6 months and successive applications for 1 year on surfaces with load.

5. SP-301 is durable for 1 year and SP-400 for 3 years. 
Table 9. Estimated costs of relocation of all the waste from a conventional burial trench (western site)

\begin{tabular}{|c|c|c|}
\hline \multirow[b]{2}{*}{ Relocation procedure } & \multicolumn{2}{|c|}{ Cost $(\$ \text { millions })^{\mathrm{a}, \mathrm{b}}$} \\
\hline & $\begin{array}{l}\text { Excavation from above } \\
\text { the trench }\end{array}$ & $\begin{array}{l}\text { Excavation from within } \\
\text { the trench }\end{array}$ \\
\hline \multicolumn{3}{|l|}{ Deep geologic disposal } \\
\hline Exhumation & 0.582 & 0.465 \\
\hline Waste management & 43.280 & 43.280 \\
\hline Total (rounded) & 43.9 & 43.7 \\
\hline \multicolumn{3}{|l|}{ Shallow-land burial } \\
\hline Exhumation & 0.582 & 0.465 \\
\hline Waste management & 7.220 & 7.220 \\
\hline Total (rounded) & 7.8 & 7.7 \\
\hline \multicolumn{3}{|l|}{ Reburial onsite } \\
\hline Exhumation & 0.582 & 0.465 \\
\hline Waste management & 0.165 & 0.165 \\
\hline Total (rounded) & 0.75 & 0.63 \\
\hline
\end{tabular}

${ }^{a}$ Number of figures shown is for computational accuracy only and does not imply precision to the nearest thousand dollars.

${ }^{b}$ Costs include $25 \%$ contingency.

Source: Murphy, E. S. and G. M. Holter. Technology, Safety and Costs of Decommissioning a Reference Low-Level Waste Burial Ground. NUREG/CR-0570, Vol. 1; Pacific Northwest Laboratory, Richland, Wash., 1980.

6. Calcium chloride is durable for $\sim 6$ months but requires frequent moistening in arid climates.

7. Liquidow is durable for $1 \frac{1 / 2}{2}$ months, magnesium chloride for 3 months, polybinder for 3 months, and lignosite for 1 year.

\subsection{COSTS OF URANIUM MILL TAILINGS STABILIZATION}

The Uranium Mill Tailings Remedial Action Program produced a number of reports (FBDU 1981a-f) that include costs. Table 12 includes estimates for a few of these sites that are representative of those in arid regions and for which figures for tons of material to be relocated are available. The authors of the report do not consider stabilization with $3 \mathrm{~m}$ cover a viable option, but cost data for doing so are included for comparison with that of other methods. 
Table 10. Cost comparison of stabilization methods for fine-sized minerals ${ }^{\mathrm{B}}$

\begin{tabular}{|c|c|c|c|}
\hline Type of stabilization & Effectiveness & Maintenance & $\begin{array}{l}\text { Approximate } \\
\text { cost per acre } \\
\text { (\$) }\end{array}$ \\
\hline \multicolumn{4}{|l|}{ Physical } \\
\hline $\begin{array}{l}\text { Water sprinkling } \\
\text { Slag (9-in. depth) }\end{array}$ & Fair & Continual & \\
\hline $\begin{array}{l}\text { By pumping } \\
\text { By trucking } \\
\text { Straw harrowing } \\
\text { Bark covering }\end{array}$ & $\begin{array}{l}\text { Good } \\
\text { Good } \\
\text { Fair } \\
\text { Good }\end{array}$ & $\begin{array}{l}\text { Moderate } \\
\text { Moderate } \\
\text { Moderate } \\
\text { Moderate }\end{array}$ & $\begin{array}{l}350-450 \\
950-1050 \\
40-75 \\
900-1000\end{array}$ \\
\hline \multicolumn{4}{|l|}{ Country gravel and soil } \\
\hline $\begin{array}{l}\text { 4-in. depth } \\
\text { 12-in. depth }\end{array}$ & $\begin{array}{l}\text { Excellent } \\
\text { Excellent }\end{array}$ & $\begin{array}{l}\text { Minimal } \\
\text { Minimal }\end{array}$ & $\begin{array}{l}250-600 \\
700-1700\end{array}$ \\
\hline \multicolumn{4}{|l|}{ Chemical } \\
\hline $\begin{array}{l}\text { Elastomeric polymer } \\
\text { Lignosulfonate }\end{array}$ & $\begin{array}{l}\text { Good } \\
\text { Good }\end{array}$ & $\begin{array}{l}\text { Moderate } \\
\text { Moderate }\end{array}$ & $\begin{array}{l}300-750^{b} \\
250-600^{b}\end{array}$ \\
\hline \multicolumn{4}{|l|}{ Vegetative } \\
\hline $\begin{array}{l}\text { 4-in. soil cover and vegetation } \\
12 \text {-in. cover and vegetation }{ }^{\mathrm{d}} \\
\text { Hydroseeding } \\
\text { Matting }^{\mathrm{e}}\end{array}$ & $\begin{array}{l}\text { Excellent } \\
\text { Excellent } \\
\text { Excellent } \\
\text { Excellent }\end{array}$ & $\begin{array}{l}\text { Minimal } \\
\text { Minimal } \\
\text { Minimal } \\
\text { Minimal }\end{array}$ & $\begin{array}{l}300-650 \\
750-1750 \\
200-450 \\
600-750^{\mathrm{b}}\end{array}$ \\
\hline Chemical-vegetative & Excellent & Minimal & $120-270^{\mathrm{b}}$ \\
\hline
\end{tabular}

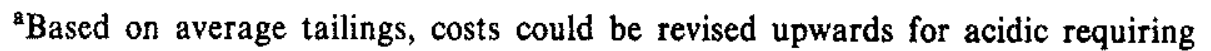
limestone or other neutralizing additives.

${ }^{b}$ The first data are derived bureau-industry costs, based upon cooperative stabilization efforts; the remaining cost data were obtained directly from industry.

${ }^{c}$ Generally used on pond areas rather than on dikes. Also, not as effective as 12-in. soil cover when tailings are excessively acidic or saline.

dSubstantiated as the optimum economic depth of soil cover when reclaiming bauxite-mined lands with soil covers ranging from 6 to 24 in., although a lesser soil cover may be satisfactory on other types of waste materials.

${ }^{\mathrm{C}}$ Based on placing 3-ft-wide matting at 3-ft intervals over the seeded area.

Source: Dean, K. C., Havens, R., and Glantz, M. V. Methods and Costs for Stabilizing Fine-Sized Mineral Wastes. U.S. Bureau of Mines Report of Investigations $7896,1974$. 
Variation in the estimates for relocation over distances of from 1 to 30 miles (1.6 to $48.3 \mathrm{~km}$ ) appears to depend upon already existing access roads, already excavated pits for disposal, and the availability and type of cover material.

Options for disposal listed in Table 12 provide for relocation of all debris and contaminated materials from tailings piles and off-site locations.

Table 11. Cost estimates for fixatives suitable for use on radioactively contaminated surfaces

\begin{tabular}{lll} 
& & \multicolumn{1}{c}{ Cost } \\
\cline { 3 - 3 } Fixative & \multicolumn{1}{c}{ Manufacturer } & \multicolumn{1}{c}{$\left(\$ / \mathrm{m}^{2}\right)$} \\
\hline & & \\
Group 1 & & \\
MC-100 & Chevron & 0.34 \\
MC-70 & Shell & $0.07-0.39$ \\
MC-70 & Representative & 0.31 \\
Emulsified asphalt & Chevron & $0.134-0.185$ \\
Emulsified asphalt & Shell & $0.27-0.29$ \\
Compound SP-301 & Johnson March & 0.23 \\
Compound SP-400 & Johnson March & 0.425 \\
& & \\
Group 2 & & \\
Road oil & WA State DOT & 0.31 \\
Road oil & Chevron & $0.32-0.37$ \\
Diesel & Chevron & 0.215 \\
Bunker oil & Chevron & $0.148-0.213$ \\
Emulsifier & Chevron & 0.149 \\
dust oil & & \\
Coherex & Witco & 0.142 \\
Calcium chloride & Van Waters \& Rogers & 0.212 \\
(Pelladow) & & \\
Liquidow & Dow & 0.412 \\
Magnesium chloride & Burris Oil & 0.60 \\
Polybinder & Burris Oil & 0.239 \\
Polybinder & Polychem & 0.224 \\
Lignosite & Georgia Pacific & 0.06 \\
Lignosite & Yakima Co. & 0.05 \\
\hline
\end{tabular}

Source: Tawil, J. and F. C. Bold, A Guide to Radiation Fixatives, PNL-4903, Pacific Northwest Laboratory, Richland, Wash., 1983. 
Table 12. Estimated costs to move contaminated soil

\begin{tabular}{|c|c|c|c|c|c|c|}
\hline \multirow[b]{2}{*}{ Site } & \multirow[b]{2}{*}{ Acres } & \multirow[b]{2}{*}{$\begin{array}{c}\text { Tons } \\
\text { material }\end{array}$} & \multicolumn{3}{|c|}{ Cost to move (\$) } & \multirow[b]{2}{*}{$\begin{array}{l}\text { Stabilization } \\
\text { with 3-m cover }\end{array}$} \\
\hline & & & $\begin{array}{l}5 \text { miles } \\
\text { or less }\end{array}$ & 5.15 miles & $\begin{array}{l}15 \text { miles } \\
\text { or more }\end{array}$ & \\
\hline Spook, Wyoming & 5 & 187,000 & $1,510,000$ & $1,700,000$ & $1,950,000$ & 710,000 \\
\hline $\begin{array}{c}\text { Tuba City, } \\
\text { Arizona }\end{array}$ & 22 & 800,000 & $21,600,000$ & $22,300,000$ & $23,100,000$ & $17,800,000$ \\
\hline $\begin{array}{l}\text { Mexican Hat, } \\
\text { Utah }\end{array}$ & $\begin{array}{l}43 \\
25\end{array}$ & $\begin{array}{r}1,320,000 \\
880,000\end{array}$ & $29,900,000$ & $34,600,000$ & $45,500,000$ & $15,200,000$ \\
\hline $\begin{array}{l}\text { Shiprock, } \\
\text { New Mexico }\end{array}$ & $\begin{array}{l}46 \\
26\end{array}$ & $\begin{array}{r}600,000 \\
1,050,000\end{array}$ & $25,600,000$ & $\begin{array}{l}27,000,000 \\
30,000,000\end{array}$ & $\begin{array}{l}34,100,000 \\
37,900,000\end{array}$ & $13,400,000$ \\
\hline $\begin{array}{l}\text { Grand Junction, } \\
\text { Colorado }\end{array}$ & 61,3 & $1,900,000$ & $\begin{array}{l}23,000,000 \\
28,500,000\end{array}$ & $\begin{array}{l}39,500,000^{\circ} \\
41,900,000^{\circ}\end{array}$ & & \\
\hline $\begin{array}{l}\text { Monument Valley, } \\
\text { Arizona }\end{array}$ & $\begin{array}{l}10 \\
20\end{array}$ & $\begin{array}{l}165,000 \\
935,000\end{array}$ & $14,300,000$ & $14,900,000$ & $15,900,000$ & $6,600,000$ \\
\hline
\end{tabular}

'Transportation by rail.

'Transportation by truck. 


\section{REFERENCES}

Ahlquist, A. J. 1981. "Los Alamos Scientific Laboratory Experience in Decontamination of the Environment," pp. 46-60 in Environmental Decontamination, Proceedings of a Workshop, CONF791234, Oak Ridge, Tenn.

Ahlquist, A. J., A. K. Stoker, and L. K. Trocki. 1977. Radiological Survey and Decontamination of the Former Main Technical Area (TA-1) at Los Alamos, New Mexico, LA-6887.

Anonymous. 1975. "Innovative Earthmoving Tools Make P\&M Coal Reclamation Project More Economical," Coal Age (Nov.) 76-79.

Baker, T. P., B. B. Boecker, and J. L. Dick. 1958. Aircraft Accidents Involving Plutonium Contamination, AFSWC-TN-583.

Barbier, M. M. 1981. "Machine Technology: A Survey," pp. 243-53 in Environmental Decontamination, Proceedings of a Workshop, CONF-791234, Oak Ridge National Laboratory, Oak Ridge, Tenn,

Barker, C. J. 1982. Removal of Plutonium-Contaminated Soil from the 903 Lip Area During 1976 and 1978, RFP-3226, Rockwell International,

Barnes, M. G., and J. J. Giacomini. 1982. "Radiological Condition of Islands," pp. 203-341 in Enewetak Radiological Support Project, Final Report, ed. B. Friesen, NVO-213,

Bicker, A. E. 1981. "Site Decontamination," pp. 91-99 in Environmental Decontamination, Proceedings of a Workshop, CONF-791234, Oak Ridge National Laboratory, Oak Ridge, Tenn.

Brown, B. L., J. L. Gardner, K. H. Guinn, C. H. Johnston, and R. D. Scanlon. 1961. Documentation of Alpha Contamination at the Nevada Test Site, RRS-61-7, Reynolds Electrical and Engineering Co., Inc.

Brown, B. L., C. R. Penwell, W. E. Moore, F. J. Sanders, and O. W. Mullen. 1964. Decontamination of Large Land Areas and Roadways at the Nevada Test Site, RRS-64-3. (Cited in Wallace and Romney 1975).

Buchholz, J. R., W. H. Adams, C. W. Christenson, and E. B. Fowler. 1971. More on the Pu Particle Size Problem, Report LADC-12898. (Cited in Wallace and Romney 1975).

Burnett, W. D., H. L. Rarrick, and G. E. Tucker. 1964. Health Physics Aspects of Operation Roller Coaster, SC-4973(RR).

Church, B. W. 1974. "What Can Be Learned from the Cleanup of the Tatum Dome Test Site, Hattiesburg, Mississippi," pp. 727-64 in Second AEC Environmental Protection Conference, WASH-1332.

Church, B. W. 1981. "Nevada Operations Overview," pp. 61-70 in Environmental Decontamination: Proceedings of a Workshop, CONF-791234, Oak Ridge National Laboratory, Oak Ridge, Tenn,

Clark, H. W. 1983. An Aerial Radiological Survey of Area 11 Nevada Test Site, EGG10282-1004. 
Corey, J. C., J. E. Pinder, and D. C. Adriano. 1978. Effect of Disking and Other Agricultural Practices on the Distribution of Surface Deposited Plutonium in Soil, Environmental Transport and Effects Research Annual Report, DP-1526, Savannah River Laboratory, pp. 173-174.

Dean, K. C., R. Havens, and M. V. Glantz. 1974. Methods and Costs for Stabilizing Fine-Sized Mineral Wastes, U.S. Bureau of Mines Report of Investigations 7896.

Defense Nuclear Agency. 1975. Environmental Impact Statement. Cleanup, Rehabilitation, Resettlement of Enewetak Atoll-Marshall Islands, Vol. 3, Washington, D.C.

Dick, J. L. and T. P. Baker. 1967. Monitoring and Decontamination Techniques for Plutonium Fallout on Large Scale Surfaces: Operation Plumbbob, Report WT-1512. (Cited in Wallace and Romney 1975).

Dunaway, P. 1982. "Plowing Philosophy and Experiment," pp. 171-73 in Enewetak Radiological Support Project, Final Report, ed. B. Friesen, NVO-213.

Dunaway, P. B., and E. R. Sorom. 1982, "Experience in Cleanup of Old Radioactive Sites. 1. Cleanup Trial in the NTS Plutonium Valley," Trans. Amer. Nucl. Soc. 43, 56.

Essington, E. H., E. B. Fowler, R. O. Gilbert, and L. L. Eberhardt. 1976. "Plutonium, Americium and Uranium Concentrations in Nevada Test Site Soil Profiles," Transuranium Nuclides in the Environment, IAEA-SM-199/76, pp. 175-73.

FBDU. 1981a. Engineering Assessment of Inactive Uranium Mill Tailings, Grand Junction, Colo,, FBDU 360-09, Ford, Bacon \& Davis Utah, Inc., Salt Lake City, Utah.

FBDU. 1981b. Engineering Assessment of Inactive Uranium Mill Tailings, Mexican Hat, Utah. FBDU 360-03, Ford, Bacon \& Davis Utah, Inc., Salt Lake City, Utah.

FBDU. 1981c. Engineering Assessment of Inactive Uranium Mill Tailings, Monument Valley, Ariz., FBDU 360-04, Ford, Bacon \& Davis Utah, Inc., Salt Lake City, Utah.

FBDU. 1981d. Engineering Assessment of Inactive Uranium Mill Tailings, Shiprock Site, NM, FBDU 360-02, Ford, Bacon \& Davis Utah, Inc., Salt Lake City, Utah.

FBDU. 1981e. Engineering Assessment of Inactive Uranium Mill Tailings, Spook Site, Converse County, Wyo. FBDU 360-15, Ford, Bacon \& Davis Utah, Inc., Salt Lake City, Utah.

FBDU. 1981f. Engineering Assessment of Inactive Uranium Mill Tailings, Tuba City, Ariz. DOE/UMT-0120, Ford, Bacon \& Davis Utah, Inc., Salt Lake City, Utah.

Fore, C. S, R. A. Faust, and R. H. Brewster. 1982. Cleanup and Treatment of Radioactively Contaminated Land Including Areas Near Nuclear Facilities: A Selected Bibliography, ORNL/EIS-199, NVO/AEIC-243,

Fowler, E. B., J. R. Buchholz, C. W. Christenson, W. H. Adams, E. R. Rodriguez, J. M. Celma, E. Iranzo, and C. A. Ramis. 1968. Soils and Plants as Indicators of the Effectiveness of a Gross Decontamination Procedure, Report LA-DC-9544. (Cited in Wallace and Romney 1975).

Frieson, B. 1982. Pilot Soil Removal Project. In: B. Friesen (Ed.), Enewetak Radiological Support Project, Final Report. NVO-213. 
Fritzsche, A. E. 1979. An Aerial Radiological Survey of Area 13 Nevada Test Site, EGG1183-1752.

Fritzsche, A. E. 1982. An Aerial Radiological Survey of Areas 1-10, 12, 15, and 17, EGG1183-1808.

Giacomini, J. J., and F. L. Miller, Jr. 1981. "Statistical Aspects of the Cleanup of Enewetak Atoll," pp. 100-103 in Environmental Decontamination, Proceedings of a Workshop, CONF-791234, Oak Ridge National Laboratory, Oak Ridge, Tenn.

Gilbert, R. O. 1977. "Revised Total Amounts of ${ }^{239,240} \mathrm{Pu}$ in Surface Soil at Safety-Shot Sites," pp. 423-29 in Transuranics in Desert Ecosystems, ed. M. G. White, P. B. Dunaway, and D. L. Wireman, NVO-181.

Gilbert, R. O., L. L. Eberhardt, E. B. Fowler, E. M. Romney, and E. H. Essington. 1975. Statistical Design and Analysis of Environmental Studies for Plutonium and Other Transuranics at NAEG "Safety-Shot" Sites, BNWL-SA-5505, CONF-751105.

Graves, A. W. 1981. "Soil Surface Decontamination and Revegetation Process," pp. 152-66 in Environmental Decontamination, Proceedings of a Workshop, Oak Ridge National Laboratory, Oak Ridge, Tenn.. CONF-791234.

Gunderson, T. C., and A. J. Ahlquist. 1979. Formerly Utilized MED/AEC Sites Remedial Action Program: Removal of a Contaminated Industrial Waste Line, Los Alamos Scientific Laboratory, Los Alamos, New Mexico, DOE/EV-0005/14.

Hartley, J. M., P. L. Koehmstedt, J. D. Esterl, H. D. Freeman, and R. L. Clark. 1980. "Applications of Asphalt Emulsion Salts to Uranium Mill Tailings," pp. 39-56 in 3rd Symposium on Uranium Mill Tailings Management, CONF-801155.

Havens, R. and K. C. Dean. 1969. Chemical Stabilization of the Uranium Tailings at Tuba City, Arizona, U.S. Bureau of Mines Report of Investigations 7288.

Hornbacher, D. D., R. M. Saiki, and C. T. Illsley. 1971. Status of Soil Stabilization Evaluation Program, International Report of Dow Chemical Company, Golden, Colo. (Cited in Wallace and Romney 1975).

Horton, J. H., and E. L. Albenesius. 1976. "Volume Reduction of Plutonium-Contaminated Soil," Nucl Tech. 30, 86-88.

Jobst, J. E. 1979. An Aerial Radiological Survey of Clean Slates 1, 2, and 3, and Double Track, Tonopah Test Range, Central Nevada, EGG-1183-1737.

Jordan, H. S. 1971. "Distribution of Plutonium from Accidents and Field Experiments," pp. 24-24 in Proceedings of Environmental Plutonium Symposium, LA-4756.

Kinnison, R. R., and R.O. Gilbert. 1980. Estimates of Soil Removal for Cleanup of Transuranics at NAEG Offsite Safety-Shot Sites, PNL-SA-8267.

Kordas, J. F. and L. R. Anspaugh. 1982. Nevada Test Site Radionuclide Inventory and Distribution Plan-Project Operations Plan, UCID-19413, Lawrence Livermore Laboratory. 
Langham, W. H. 1968. The Problem of Large-Area Plutonium Contamination, Seminar Paper No. 002, National Center for Radiological Health Seminar, Rockville, Md.

Lee, H., J. D. Sartor, and W. H. Van Horn. 1959. "Stoneman II Test of Reclamation Performance," Vol. IV, Performance Characteristics of Land Reclamation Procedures, USNRDLTR-337.

Lee, S. Y., and T. Tamura. 1981. "Distribution and Characterization of Radionuclides in Soils from the Nevada Test Site." J. Environ. Qual. 10(2), 234-39.

Lindsay, J. W., D. E. Michaels, and J. A. Martinez. 1973. Scavenging Contaminated Soil with Polyurethane Foam, RFP-1949, Dow Chemical Company.

Martin, D. 1979. "Asphalt and Cement Promise Savings in Stabilization of Mill Tailings," Nuclear Fuel 4(8), 13-14.

Martin, W. E. and S. G. Bloom. 1977. "Nevada Applied Ecology Group Model for Estimating Plutonium Transport and Dose to Man," pp. 621-706 in Transuranics in Natural Environments, NVO-178.

McKinley, K. B., and J. D. McKinney. 1978. Early Waste Retrieval Interim Report, TREE-1265.

McKnight, R. K., C. E. Rosenberry and J. A. Orcutt. 1984. Nevada Test Site Area 25 Radiological Survey and Cleanup Project, 1974-1983, Final Report. DOE/NV/10327-5.

McMahon, L. A. 1979. 1980 Dodge Guide to Public Works and Heavy Construction Costs, McGraw-Hill, N.Y.

Menzel, R. G. and P. E. James. 1959. "Physical Removal of Radioactive Surface Contamination from Agricultural Land.” pp. 45-59 in Proceedings of the Thirty-fifth Annual Meeting of the National Joint Committee on Fertilizer Application, National Plant Institute, Washington, D.C.

Miller, C. F. 1958. The Radiological Assessment and Recovery of Contaminated Areas, CEX-57.1.

Murphy, E. S., and G. M. Holter. 1980. Technology, Safety and Costs of Decommissioning a Reference Low-Level Waste Burial Ground, NUREG/CR-0570, vol. 1, Pacific Northwest Laboratory, Richland, Wash.

Orcutt, J. A. 1982. Cleanup and Treatment (CAT) Test: A Land Area Decontamination Project Utilizing a Vacuum Method of Soil Removal, DOE/NV/00410-70.

Pinson, E. A., R. F. Merian, B. B. Boecker, and J. L. Dick. 1957. Operation Plumbob-Test Group 57, Program 73, Monitoring and Decontamination Techniques for Plutonium Fallout on LargeArea Surfaces, ITR-1512-DEL.

Rarrick, H. L. 1972. "Weapons Effects Tests--Planned Emergencies," pp. 1573-80 in Health Physics Operational Monitoring, eds. C.A. Willis and J.S. Handloser, CONF-690103.

Reynolds Electrical \& Engineering Co., Inc. 1980. Nevada Test Site Radioactive Waste Management Consolidation Plan, Completion Report, Fiscal Year 1980. 
Reynolds Electrical \& Engineering Co., Inc. 1983. Nevada Test Site Radioactive Waste Consolidation Plan, Completion Report, Fiscal Year 1983.

Rishel, H. L., T. M. Boston, and C. J. Schmidt. 1982. Costs of Remedial Response Actions at Uncontrolled Hazardous Waste Sites, EPA-600/2-82-035, SCS Engineers, Long Beach, Calif., pp. 22-25, and Tables, pp. 125-44).

Robert S. Means Company. 1979. Building Construction Cost Data 1980, Duxbury, Miss.

Sanders, F. 1966. Decontamination of Test Cell C at the Nuclear Rocket Development Station, Report LA-3633-MS, (Cited in Wallace and Romney 1975).

Smith, W. J., E. B. Fowler, and R. G. Stafford. 1977. Experience in the Cleanup of PlutoniumContaminated Land, LA-6731-MS.

Stevens, J. R., R. L. Kochen, and D. W. Rutherford. 1982. Comparative Scrub Solution Tests for Decontamination of Transuranic Radionuclides from Soils. Rockwell International Report RFP. 3161 .

Straume, T., C. R. Kellner, and K. M. Oswald. 1977. Cleanup of Radioactive Mud Spill U20aa Postshot Drilling Site, NTS, UCID-17423.

Straume, T., C. R. Kellner, and K. M. Oswald. 1978. "Radioactive Decontamination Methods and Their Effectiveness as a Function of Terrain," Health Physics 35 309-14.

Tawil, J. and F. C. Bold. 1983. A Guide to Radiation Fixatives, PNL-4903, Pacific Northwest Laboratory, Richland, Wash.

Tipton, W. J. 1979. An Aerial Radiological Survey of Areas 25 and 26, Nevada Test Site. EGG1183-1745, EG\&G Energy Measurements Group.

Tipton, W. J., A. A. Fritzsche, R. J. Jaffe, and A. E. Villaire. 1981. An in situ Determination of ${ }^{241}$ Am on Enewetak Atoll, EGG-1183-1778, EG\&G Energy Measurements Group.

Wallace, A. and E. M. Romney. 1975. "Feasibility and Alternate Procedures for Decontamination and Post-Treatment Management of Pu-Contaminated Areas in Nevada." UCLA-12-973 (1974). pp. 251-337 in The Radioecology of Plutonium and Other Transuranics in Desert Environments, eds. M. G. White and P. B. Dunaway, NVO-153.

Wallace, A., and E. M. Romney. 1977. "Initial Land Reclamation Procedures Related to Possible Pu-Cleanup Activities at the Tonopah Test Range." UCLA-12-1054, and pp. 65-77 in Environmental Plutonium on the Nevada Test Site and Environs, NVO-171.

U.S. Department of Energy. 1983. Announced United States Nuclear Tests, NVO-209. 

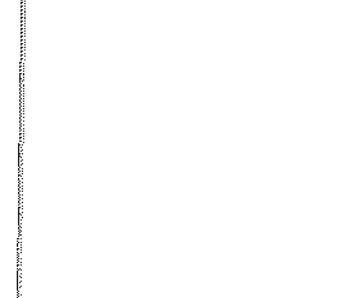

.
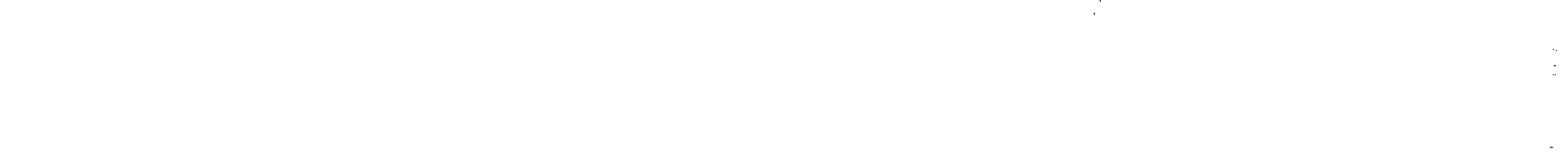

.

. . 列 


\section{APPENDIX A ADDITIONAL PUBLICATIONS CONTAINING COST DATA}

An extensive search was made for cost data of use to those who will be cleaning up radioactively contaminated sites. In addition to reports listed in the bibliography, some cost data were found in the following publications:

Ahlquist, A. J., A. K. Stoker, and L. K. Trocki. 1977. Radiological Survey and Decontamination of the Former Main Technical Area (TA-1) at Los Alamos, New Mexico, LA-6887, Los Alamos Scientific Laboratory, Los Alamos, N.M.

Bechtel National, Inc. 1984. Final Report on Remedial Action at the Acid/Pueblo Canyon Site Los Alamos, New Mexico, Advanced Technology Division, DOE/OR/20722-15, Oak Ridge National Laboratory, Oak Ridge, Tenn.

Bengson, S. A. 1979. "Irrigation Techniques for Tailing Revegetation in the Arid Southwest," ASARCO, Inc., Mission Unit, Sahuarita, AZ, Tailing Disposal Today, Vol. 2, G. O. Argall, Jr. (Ed.), Proceedings of the Second International Tailing Symposium, Denver, Colo. May 1978, (pp. 487-503). Miller Freeman Publications, Inc., San Francisco, Calif.,

Chapin, J. A. 1979. Characterization of the TAN-TSF Outside Areas, Final Report, PR-W79-031, EG\&G Idaho, Inc., Idaho Falls, Idaho,

Church, B. W. 1981. "Nevada Operation Overview," Nevada Operations Office, US ERDA, Las Vegas, NV, CONF-79123; Environmental Decontamination, Proceedings of a Workshop, Oak Ridge National Laboratory, Oak Ridge, Tenn., December 4-5, 1979, pp. 61-6),

Dean, K.C., R. Havens, and K.T. Harper. 1969. Chemical and Vegetative Stabilization of a Nevada Copper Porphyry Mill Tailing, U.S. Bureau of Mines Report of Investigations 7261, Salt Lake City Metallurgy Research Center, Salt Lake City, Utah.

FBDU 1981. Engineering Assessment of Inactive Uranium Mill Tailings, New and Old Rifle Sites, Rifle, Colorado, DOE/UMT-0108, Ford, Bacon \& Davis Utah, Inc., Salt Lake City, Utah.

FBDU 1981. Engineering Assessment of Inactive Uranium Mill Tailings, Bowman Site, Bowman, N.D., DOE/UMT-0121, Ford, Bacon \& Davis Utah, Inc., Salt Lake City, Utah.

FBDU 1981. Engineering Assessment of Inactive Uranium Mill Tailings, Durango, Site, Durango, Colorado, DOE/UMT-0103, FBDU 360-06, Ford, Bacon \& Davis Utah, Inc., Salt Lake City, Utah.

FBDU 1981. Engineering Assessment of Inactive Uranium Mill Tailings, Green River Site, Green River, Utah, FBDU 360-14, Ford, Bacon \& Davis Utah, Inc., Salt Lake City, Utah.

FBDU 1981. Engineering Assessment of Inactive Uranium Mill Tailings, Gunnison Site, Gunnison, Colorado, DOE/UMT-0107, FBDU 360-12, Ford, Bacon \& Davis Utah, Inc., Salt Lake City, Utah.

FBDU 1981. Engineering Assessment of Inactive Uranium Mill Tailings, Maybell Site, Maybell, Colorado, DOE/UMT-0116, FBDU 360-11, Ford, Bacon \& Davis Utah, Inc., Salt Lake City, Utah.

FBDU 1981. Phase 2-Title 1 Engineering Assessment of Inactive Uranium Mill Tailings New and Old Rifle Sites, Rifle, Colorado, GJT-10, FBDU 130-10, Ford, Bacon \& Davis Utah, Inc., Salt Lake City, Utah.

Hartley, J. N., G. W. Gee, E. G. Baker, and H. D. Freeman. 1983. 1981 Radon Barrier Field Test at Grand Junction Uranium Mill Tailings Pile, DOE/UMT-0213, PNL-4539, Pacific Northwest Laboratory, Richland, Wash. 
Havens, R., and K. C. Dean. 1969. Chemical Stabilization of the Uranium Tailings at Tuba City, Arizona, U.S. Bureau of Mines Report of Investigations 7288, Salt Lake City Metallurgy Research Center, Salt Lake City, Utah,

Milier, R. L., W. F. Downs, and J. E. Flinn. 1979. Preliminary Assessment for Decontamination of Idaho National Engineering Laboratory Radioactive Soils Using Chemical Extraction Processes, RE-M-79-012, EG\&G Idaho, Inc., Fuels and Materials Division, Las Vegas, Nev.,

Murray, D., and D. Moffert. 1977. Vegetating the Uranium Mine Tailings at Elliot Lake, Ontario, Canada Centre for Mineral and Energy Technology, Mining Research Laboratories. Elliot Lake Laboratory, Elliot Lake, Ontario, Canada, Soil and Water Conservation 32(4):171-174.

Smith, W.J., II, E. B. Fowler, and R. G. Stafford. 1977. Experience in the Cleanup of PlutoniumContaminated Land, LA-6731-MS, Los Alamos Scientific Laboratory, Los Alamos, N.M., 


\section{APPENDIX B COMPONENT COST DATA FOR LANDFILL AND SURFACE IMPOUNDMENT OPERATIONS}

Tables included in this appendix are taken from a 1982 U.S. Environmental Protection Agency report (EPA-600/2-035) prepared by Rishel et al. The tables contain a description of each component, with cost data for that component and costs for geographical areas in the United States (U.S. low and U.S. high) that were computed from the source data. Regional adjustments for costs were made using adjustment indices in the Dodge Guide (McMahon 1979). No regional adjustment index was available for equipment costs, so it was assumed that these costs are the same around the nation.

Table B.1 includes landfill capital cost component data. Overhead and maintenance costs for landfill operations are found in Table B.2. Tables B.3 and B.4 provide similar data for surface impoundment operations.

These cost data are provided as an example of component cost computation. It is suggested that the reader consult the EPA report for a more detailed description of the actual costing methodology. 
Table B.1 Landfill capital cost components

\begin{tabular}{|c|c|c|c|c|c|c|}
\hline \multirow[b]{2}{*}{ Component } & \multirow[b]{2}{*}{ Subcomponent } & \multirow[b]{2}{*}{ Definition } & \multicolumn{4}{|c|}{ U.S. Dollars } \\
\hline & & & $\begin{array}{l}\text { Metric } \\
\text { units }\end{array}$ & $\begin{array}{l}\text { Source } \\
\text { cost }\end{array}$ & $\begin{array}{l}\text { U.S. } \\
\text { low }\end{array}$ & $\begin{array}{l}\text { U.S. } \\
\text { bigh }\end{array}$ \\
\hline Apply stabilized & Installation & $\begin{array}{l}\text { Hauling and spreading, } 10 \\
\text { miles }(16 \mathrm{~km}) \text {, round-trip }\end{array}$ & $\mathbf{m}^{3}$ & 8.76 & 5.52 & 11.5 \\
\hline Area preparation & Labor & Rake and cleanup, average & ha & 741 & 469 & 963 \\
\hline Area preparation & Equipment & Rake and cleanup, average & ha & 222 & 222 & 222 \\
\hline Backfill & Labor & Dozer and sheepsfoot roller & $\mathbf{m}^{3}$ & 0.51 & 0.32 & 0.64 \\
\hline Backfill & Equipment & Dozer and sheepsfoot roller & $\mathrm{m}^{3}$ & 1.44 & 1.44 & 1.44 \\
\hline Bentonite, delivered & $\begin{array}{r}\text { Materials/ } \\
\text { shipping }\end{array}$ & $\begin{array}{l}\text { Shipment of bentonite } \\
\text { by rail }\end{array}$ & tonne & 66.4 & 177 & 166 \\
\hline Berm construction & $\begin{array}{l}\text { Materials/ } \\
\text { installation }\end{array}$ & Use scraper & $\mathbf{m}^{3}$ & 0.50 & 0.35 & 0.60 \\
\hline Blower & $\begin{array}{l}\text { Materials/ } \\
\text { installation }\end{array}$ & Blower, air & each & 1,150 & 800 & 1,360 \\
\hline Butterfly valves, 6 in. & $\begin{array}{l}\text { Materials/ } \\
\text { installation }\end{array}$ & PVC valve & each & 192 & 135 & 230 \\
\hline Butterfly valves, 8 in. & $\begin{array}{l}\text { Materials/ } \\
\text { installation }\end{array}$ & PVC valve & each & 304 & 213 & 360 \\
\hline $\begin{array}{l}\text { Cement pipe, } 4 \text { in. } \\
\text { perforated }\end{array}$ & Labor & $\begin{array}{l}\text { Asbestos, Class } 4000 \\
\text { underdrain }\end{array}$ & m & 3.00 & 1.90 & 3.18 \\
\hline $\begin{array}{l}\text { Cement pipe, } 4 \text { in. } \\
\text { perforated }\end{array}$ & Materials & $\begin{array}{l}\text { Asbestos, Class } 4000 \\
\text { underdrain }\end{array}$ & $\mathbf{m}$ & 5.08 & 3.91 & 5.38 \\
\hline $\begin{array}{l}\text { Cement pipe, } 6 \mathrm{in} \\
\text { perforated }\end{array}$ & Labor & $\begin{array}{l}\text { Asbestos, Class } 4000 \\
\text { underdrain }\end{array}$ & m & 3.10 & 1.95 & 4.06 \\
\hline $\begin{array}{l}\text { Cement pipe, } 6 \text { in. } \\
\text { perforated }\end{array}$ & Materials & $\begin{array}{l}\text { Asbestos, Class } 4000 \\
\text { underdrain }\end{array}$ & $\mathbf{m}$ & 8.00 & 6.16 & 8.48 \\
\hline Cement pipe, 6 in. & Labor & Cement pipe, nonperforated & $\mathbf{m}$ & 3.54 & 2.23 & 4.63 \\
\hline Cement pipe, 6 in. & Materials & Cement pipe, nonperforated & m & 6.23 & 4.80 & 6.60 \\
\hline Chemicals & Materials & $\begin{array}{l}\text { Treatment chemical, sodium } \\
\text { hypochlorite }(\mathrm{NaCl})\end{array}$ & $\mathrm{L}$ & 0.16 & 0.12 & 0.17 \\
\hline Deep wells, 6 in. & Materials/labor & Drilled and cased & m & 20.9 & 14.6 & 25.1 \\
\hline Dewatering system & Materials/labor & $\begin{array}{l}\text { For cost breakdowns, see } \\
\text { "Discharge pipe," } \\
\text { "Submersible pump," } \\
\text { "Deep wells" }\end{array}$ & & & & \\
\hline Discharge pipe, 4 in. & Labor & PVC plastic, Schedule 40 & m & 22.0 & 13.9 & 28.8 \\
\hline Discharge pipe, 4 in. & Materials & PVC plastic, Schedule 40 & m & 9.15 & 7.05 & 9.70 \\
\hline Discharge pipe, 8 in. & Labor & PVC plastic, Schedule 40 & m & 34.1 & 21.5 & 44.7 \\
\hline Discharge pipe, 8 in. & Materials & PVC plastic, Schedule 40 & $\mathbf{m}$ & 27.4 & 21.1 & 29.0 \\
\hline $\begin{array}{l}\text { Diversion ditch, } \\
\text { construction }\end{array}$ & Installation & $\begin{array}{l}\text { Construction and maintenance/ } \\
\text { repair }\end{array}$ & $\mathbf{m}$ & 2.78 & 1.75 & 3.63 \\
\hline Drilled holes, 2.5 in. & $\begin{array}{l}\text { Materials/ } \\
\text { installation }\end{array}$ & Drilled and cased with pipe & $m$ & 18.3 & 11.6 & 24.1 \\
\hline
\end{tabular}


Table B.1 (contioned)

\begin{tabular}{|c|c|c|c|c|c|c|}
\hline \multirow[b]{2}{*}{ Component } & \multirow[b]{2}{*}{ Subcomponent } & \multirow[b]{2}{*}{ Definition } & \multicolumn{4}{|c|}{ U.S. Dollars } \\
\hline & & & $\begin{array}{l}\text { Metric } \\
\text { units }\end{array}$ & $\begin{array}{l}\text { Source } \\
\text { cost }\end{array}$ & $\begin{array}{l}\text { U.S. } \\
\text { low }\end{array}$ & $\begin{array}{l}\text { U.S. } \\
\text { high }\end{array}$ \\
\hline Drilled holes, 6 in. & $\begin{array}{l}\text { Materials/ } \\
\text { installation }\end{array}$ & Drilled and cased with pipe & $\mathbf{m}$ & 22.3 & 15.6 & 26.4 \\
\hline Drill rig & $\begin{array}{l}\text { Rental } \\
\text { (equip./labor) }\end{array}$ & $\begin{array}{l}\text { Crew and light-duty rig, } \\
\text { and grading }\end{array}$ & day & 400 & 280 & 470 \\
\hline $\begin{array}{l}\text { Excavation, drainage } \\
\text { trench }\end{array}$ & Labor & Use backhoe loader & $\mathbf{m}^{3}$ & 2.65 & 1.70 & 3.50 \\
\hline $\begin{array}{l}\text { Excavation, drainage } \\
\text { trench }\end{array}$ & Materials & Use backhoe loader & $\mathbf{m}^{3}$ & 1.60 & 1.20 & 1.70 \\
\hline $\begin{array}{l}\text { Excavation/grading, } \\
\text { soil }\end{array}$ & Labor & $\begin{array}{l}\text { Excavation/grading, soil, } \\
\text { common borrow, 1000-ft } \\
(305-\mathrm{m}) \text { baul }\end{array}$ & $\mathrm{m}^{3}$ & 0.22 & 0.14 & 0.29 \\
\hline $\begin{array}{l}\text { Excavation/grading, } \\
\text { soil }\end{array}$ & Equipment & $\begin{array}{l}\text { Excavation/grading, soil, } \\
\text { common borrow, 1000-ft } \\
(305-\mathrm{m}) \text { haul }\end{array}$ & m & 0.76 & 0.76 & 0.76 \\
\hline $\begin{array}{l}\text { Excavation, grading, } \\
\text { and recontouring } \\
\text { of site }\end{array}$ & Labor & $\begin{array}{l}300-\mathrm{ft}(90-\mathrm{m}) \text { haul, dozer } \\
\text { and truck }\end{array}$ & $\mathbf{m}^{3}$ & 0.37 & 0.23 & 0.48 \\
\hline $\begin{array}{l}\text { Excavation, grading, } \\
\text { and recontouring } \\
\text { of site }\end{array}$ & Equipment & $\begin{array}{l}300-\mathrm{ft}(90-\mathrm{m}) \text { haul, dozer } \\
\text { and truck }\end{array}$ & $\mathbf{m}$ & 1.35 & 1.35 & 1.35 \\
\hline Exploratory boring & $\begin{array}{l}\text { Materials/ } \\
\text { installation }\end{array}$ & $\begin{array}{l}\text { Test strata in or below } \\
\text { landfill, and to apply } \\
\text { chemical injection, } 4 \text {-in. } \\
(0.03-\mathrm{m}) \text {-diam holes }\end{array}$ & $\mathbf{m}$ & 19.7 & 13.8 & 23.2 \\
\hline Flow meters, 6 in. & $\begin{array}{l}\text { Materials/ } \\
\text { installation }\end{array}$ & $\begin{array}{l}\text { Measures rate of flow of } \\
\text { landfill gas to blower }\end{array}$ & each & 880 & 550 & 1,150 \\
\hline Flow meters, 8 in. & $\begin{array}{l}\text { Materials/ } \\
\text { installation }\end{array}$ & $\begin{array}{l}\text { Measures rate of flow of } \\
\text { landfill gas to blower }\end{array}$ & each & 1,040 & 650 & 1,360 \\
\hline $\begin{array}{l}\text { Geotechnical } \\
\text { investigation }\end{array}$ & Labor/materials & $\begin{array}{l}\text { Includes exploratory holes, } \\
\text { surveying, mobilization, } \\
\text { drilling addition, pump } \\
\text { test, and report }\end{array}$ & site & 5,500 & 3,850 & 6,520 \\
\hline Gravel & Labor & $\begin{array}{l}\text { One dozer operator, one } \\
\text { truck driver }\end{array}$ & $\mathrm{m}^{3}$ & 2.48 & 1.5 & 3.25 \\
\hline Gravel & Materials & $3 / 4$ in. screened gravel & $\mathrm{m}^{3}$ & 7.20 & 5.54 & 7.63 \\
\hline Grout curtain & Labor & $\begin{array}{l}\text { Two grid-phenolic resin } \\
\text { (also for grout bottom } \\
\text { seal) }\end{array}$ & $\mathrm{m}^{3}$ & 262 & 165 & 343 \\
\hline Grout curtain & Materials & $\begin{array}{l}\text { Two grid-phenolic resin } \\
\text { (also for grout bottom } \\
\text { seal) }\end{array}$ & m & 56.2 & 43.3 & 59.6 \\
\hline Header pipe, 8 in. & Materials & PVC Schedule 40 & $\mathbf{m}$ & 27.4 & 21.1 & 29.0 \\
\hline Header pipe, 8 in. & Installation & PVC Schedule 40 & $\mathrm{~m}$ & 34.1 & 21.5 & 44.7 \\
\hline Hydroseeding & Labor & $\begin{array}{l}\text { Includes seed and soil } \\
\text { supplements }\end{array}$ & ha & 171 & 108 & 224 \\
\hline
\end{tabular}


Table B.1 (continued)

\begin{tabular}{|c|c|c|c|c|c|c|}
\hline \multirow[b]{2}{*}{ Component } & \multirow[b]{2}{*}{ Subcomponent } & \multirow[b]{2}{*}{ Definition } & \multicolumn{4}{|c|}{ U.S. Dollars } \\
\hline & & & $\begin{array}{l}\text { Metric } \\
\text { units }\end{array}$ & $\begin{array}{l}\text { Source } \\
\text { cost }\end{array}$ & $\begin{array}{l}\text { U.S. } \\
\text { low }\end{array}$ & $\begin{array}{l}\text { U.S. } \\
\text { high }\end{array}$ \\
\hline Hydroseeding & Materials & $\begin{array}{l}\text { Includes seed and soil } \\
\text { supplements }\end{array}$ & ha & 877 & 675 & 929 \\
\hline Hydroseeding & Equipment & $\begin{array}{l}\text { Includes seed and soil } \\
\text { supplements }\end{array}$ & ha & 124 & 124 & 124 \\
\hline Liner & Labor/materials & $\begin{array}{l}30 \text { mil., bracketed with } \\
\text { beavyweight geotextile } \\
\text { fabric, Hypaion }\end{array}$ & $\mathbf{m}^{2}$ & 6.22 & 4.35 & 7.37 \\
\hline Materials testing & $\begin{array}{l}\text { Materials/ } \\
\text { installation }\end{array}$ & $\begin{array}{l}\text { For costing, see "Exploratory } \\
\text { boring" }\end{array}$ & & & & \\
\hline Moisture traps & $\begin{array}{l}\text { Materials/ } \\
\text { installation }\end{array}$ & $\begin{array}{l}\text { Removes water from gas } \\
\text { control system }\end{array}$ & each & 480 & 335 & 570 \\
\hline Monitoring equipment & Equipment & $\begin{array}{l}\text { Gas detection instrumentation } \\
\text { to monitor gas control } \\
\text { Bystems (MSA Model } 53 \\
\text { Gascope) }\end{array}$ & each & 500 & 500 & 500 \\
\hline Monitoring wells, gas & Materials & $\begin{array}{l}0.5 \text { in. }(1.3 \mathrm{~cm}), 12 \mathrm{ft} \\
(3.6 \mathrm{~m}) \text { deep for landfill } \\
\text { gas monitoring }\end{array}$ & $\mathbf{m}$ & 1.34 & 1.03 & 1.42 \\
\hline Monitoring wells, gas & Installation & $\begin{array}{l}0.5 \mathrm{in} .(1.3 \mathrm{~cm}), 12 \mathrm{ft} \\
(3.6 \mathrm{~m}) \text { deep for landfill } \\
\text { gas monitoring }\end{array}$ & $\mathbf{m}$ & 8.82 & 5.55 & 11.5 \\
\hline Mulching & Labor & Hay mulching & ha & 85.2 & 53.7 & 111 \\
\hline Mulching & Materials & Hay mulching & ha & 210 & 162 & 223 \\
\hline Mulching & Equipment & Hay mulching & ha & 57.3 & 57.3 & 57.3 \\
\hline Pipe, PVC (elbows), 6 in. & Materials & $90 \mathrm{in.} \mathrm{fitting}$ & each & 27.0 & 20.8 & 28.6 \\
\hline Pipe, PVC (elbows), 6 in. & Installation & 90 in. fitting & each & 28.0 & 17.6 & 36.7 \\
\hline Pipe, PVC (elbows), 8 in. & Materials & 90 in. fitting & each & 52.0 & 40.0 & 55.1 \\
\hline Pipe, PVC (elbows), 8 in. & Installation & 90 in. fitting & each & 39.0 & 24.6 & 51.1 \\
\hline Pipe, PVC (Tees), 6 in. & Materials & T-fittings for gas wells & each & 37.0 & 28.5 & 39.2 \\
\hline Pipe, PVC (Tees), 6 in. & Installation & T-fittings for gas wells & each & 46.0 & 29.0 & 60.3 \\
\hline Pipe, PVC (Tees), 8 in. & Materials & T-fittings for gas wells & each & 75.0 & 57.8 & 79.5 \\
\hline Pipe, PVC (Tees), 8 in. & Installation & T-fittings for gas wells & each & 59.0 & 37.2 & 77.3 \\
\hline Pipe, PVC, laterals, 8 in. & Materials & $\begin{array}{l}\text { For gas extraction wells } \\
\text { Schedule } 40 \text { (includes } \\
\$ 4.92 / \mathrm{m} \text { for perforations) }\end{array}$ & each & 29.20 & 22.5 & 30.9 \\
\hline Pipe, PVC, laterals, 8 in. & Installation & $\begin{array}{l}\text { For gas extraction wells, } \\
\text { Schedule } 40\end{array}$ & $\mathbf{m}$ & 9.65 & 6.08 & 12.6 \\
\hline Pipe, PVC, laterals, 12 in. & Materials & $\begin{array}{l}\text { For gas extraction wells, } \\
\text { Schedule } 40 \text { (includes } \\
\$ 4.92 / \mathrm{m} \text { for perforations) }\end{array}$ & $\mathbf{m}$ & 41.0 & 31.6 & 43.7 \\
\hline Pipe, PVC, laterals, 12 in. & Installation & $\begin{array}{l}\text { For gas extraction wells, } \\
\text { Schedule } 40\end{array}$ & $\mathbf{m}$ & 15.4 & 11.9 & 16.4 \\
\hline
\end{tabular}


Trable B.1 (continued)

\begin{tabular}{|c|c|c|c|c|c|c|}
\hline \multirow[b]{2}{*}{ Component } & \multirow[b]{2}{*}{ Subcomponent } & \multirow[b]{2}{*}{ Definition } & \multicolumn{4}{|c|}{ U.S. Dollars } \\
\hline & & & $\begin{array}{l}\text { Metric } \\
\text { units }\end{array}$ & $\begin{array}{l}\text { Source } \\
\text { cost }\end{array}$ & $\begin{array}{l}\text { U.S. } \\
\text { low }\end{array}$ & $\begin{array}{l}\text { U.S. } \\
\text { high }\end{array}$ \\
\hline Pipe, PVC, risers, 4 in. & Materials & $\begin{array}{l}\text { For gas extraction wells, } \\
\text { Schedule } 40\end{array}$ & m & 9.15 & 7.05 & 9.70 \\
\hline Pipe, PVC, risers, 4 in. & Installation & $\begin{array}{l}\text { For gas extraction wells, } \\
\text { Schedule } 40\end{array}$ & $\mathbf{m}$ & 22.0 & 13.9 & 28.8 \\
\hline Pipe, PVC, risers, 6 in. & Materials & $\begin{array}{l}\text { For gas extraction wells, } \\
\text { Schedule } 40\end{array}$ & $\mathbf{m}$ & 16.4 & 12.7 & 17.4 \\
\hline Pipe, PVC, risers, 6 in. & Installation & $\begin{array}{l}\text { For gas extraction wells, } \\
\text { Schedule } 40\end{array}$ & m & 25.7 & 16.2 & 33.7 \\
\hline Pump, centrifugal & $\begin{array}{l}\text { Equipment / } \\
\text { installation }\end{array}$ & 3/4-hp pump & each & 1,600 & 1,600 & 1,600 \\
\hline Pump, submersible & Labor & $1 \mathrm{hp}-4$ in., submersible & each & 344 & 220 & 450 \\
\hline Pump, submersible & Materials & $1 \mathrm{hp}-4$ in., submersible & each & 424 & 330 & 450 \\
\hline Recharge trench & $\begin{array}{l}\text { Materials/ } \\
\text { installation }\end{array}$ & Excavation of trench & $\mathbf{m}^{3}$ & 1.60 & 1.12 & 1.90 \\
\hline Sand & $\begin{array}{l}\text { Materials/ } \\
\text { installation }\end{array}$ & $\begin{array}{l}\text { For well point casing } \\
\text { backffill }\end{array}$ & bag & 5.80 & 4,06 & 6.87 \\
\hline Sheet piling & Materials & $\begin{array}{l}\text { Steel sheet, PMA-22 } \\
\left(22 \mathrm{lb} / \mathrm{ft}^{2}\right)\end{array}$ & tonne & 507 & 390 & 537 \\
\hline Sheet piling & Installation & 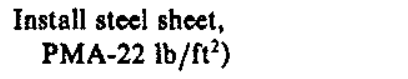 & tonne & 100 & 63 & 131 \\
\hline $\begin{array}{l}\text { Slurry trench } \\
\text { excavation }\end{array}$ & $\begin{array}{l}\text { Materials/ } \\
\text { installation }\end{array}$ & $\begin{array}{l}\text { Includes installation of } \\
\text { bentonite slurry }\end{array}$ & $\mathrm{m}^{3}$ & 46.0 & 32.2 & 54.5 \\
\hline Spread excavated material & Labor & $\begin{array}{l}\text { One equipment operator, } \\
\text { five laborers }\end{array}$ & $\mathrm{m}^{3}$ & 0.21 & 0.13 & 0.25 \\
\hline Spread excavated material & Equipment & $\begin{array}{l}\text { Spread by dozer, no } \\
\text { compaction }\end{array}$ & $\mathrm{m}^{3}$ & 0.51 & 0.51 & 0.51 \\
\hline $\begin{array}{l}\text { Surface seal, bituminous } \\
\text { concrete }\end{array}$ & Installation & $3 \mathrm{in},-(0.08-\mathrm{m})-$ thick cap & $\mathrm{m}^{2}$ & 1.05 & 0.66 & 1.37 \\
\hline $\begin{array}{l}\text { Surface seal, bituminous } \\
\text { concrete }\end{array}$ & Materials & 3 in $-(0.08 \mathrm{~m})-$ thick cap & $\mathbf{m}^{2}$ & 3.00 & 2.31 & 3.18 \\
\hline Surface seal, clay cap & $\begin{array}{l}\text { Materials/ } \\
\text { installation }\end{array}$ & $\begin{array}{l}6 \text { in. }(15-\mathrm{cm}) \text { clay cap, includes } \\
18 \text { in. }(46-\mathrm{cm}) \text { soil cover }\end{array}$ & $\mathbf{m}^{2}$ & 4.82 & 3.50 & 6.41 \\
\hline Surface seal, clay cap & $\begin{array}{l}\text { Materials/ } \\
\text { installation }\end{array}$ & $\begin{array}{l}18 \text { in. }(46-\mathrm{cm}) \text { clay cap includes } \\
18 \mathrm{in} .(46-\mathrm{cm}) \text { soll cover }\end{array}$ & $\mathrm{m}^{2}$ & 6.18 & 4.51 & 8.22 \\
\hline Surface seal, fly ash cap & $\begin{array}{l}\text { Materials/ } \\
\text { installation }\end{array}$ & $\begin{array}{l}12 \text { in. }(30-\mathrm{cm}) \text { fly ash cap } \\
\text { includes } 18 \text { in. }(46-\mathrm{cm}) \text { soil } \\
\text { cover }\end{array}$ & $\mathrm{m}^{2}$ & 4.65 & 3.40 & 6.18 \\
\hline Surface seal, fly ash cap & $\begin{array}{l}\text { Material/ } \\
\text { installation }\end{array}$ & $\begin{array}{l}24 \text { in. }(60-\mathrm{cm}) \text { fly ash cap, } \\
\text { includes } 18 \text { in. }(46-\mathrm{cm}) \text { soil } \\
\text { cover }\end{array}$ & $\mathbf{m}^{2}$ & 6.27 & 4.49 & 8.36 \\
\hline Surface seal, fly ash cap & $\begin{array}{l}\text { Material/ } \\
\quad \text { installation }\end{array}$ & $\begin{array}{l}5 \text { in. }(13-\mathrm{cm}) \text { lime-stabilized } \\
\text { cap, includes } 18 \text { in. (46-cm) } \\
\text { soil cover }\end{array}$ & $\mathbf{m}^{2}$ & 6.05 & 5.24 & 8.04 \\
\hline $\begin{array}{l}\text { Surface seal, PVC } \\
\text { membrane cap }\end{array}$ & $\begin{array}{l}\text { Materials/ } \\
\text { installation }\end{array}$ & $\begin{array}{l}30 \text { mil PVC membrane cap, } \\
\text { includes } 18 \text { in. }(46-\mathrm{cm}) \text { soil } \\
\text { cover }\end{array}$ & $\mathrm{m}^{2}$ & 10.8 & 9.7 & 14.4 \\
\hline
\end{tabular}


Table B.1 (continued)

\begin{tabular}{|c|c|c|c|c|c|c|}
\hline \multirow[b]{2}{*}{ Component } & \multirow[b]{2}{*}{ Subcomponent } & \multirow[b]{2}{*}{ Definition } & \multicolumn{4}{|c|}{ U.S. Dollars } \\
\hline & & & $\begin{array}{l}\text { Metric } \\
\text { units }\end{array}$ & $\begin{array}{l}\text { Source } \\
\text { cost }\end{array}$ & $\begin{array}{l}\text { U.S. } \\
\text { low }\end{array}$ & $\begin{array}{l}\text { U.S. } \\
\text { high }\end{array}$ \\
\hline $\begin{array}{l}\text { Surface seal, soil-cement } \\
\text { cap }\end{array}$ & $\begin{array}{l}\text { Materials/ } \\
\text { installation }\end{array}$ & $\begin{array}{l}5 \text { in. }(13-\mathrm{cm}) \text { soil-cement cap, } \\
\text { includes } 18 \text { in. }(46-\mathrm{cm}) \text { soil } \\
\text { cover }\end{array}$ & $\mathrm{m}^{2}$ & 6.05 & 5.24 & 8.04 \\
\hline Surveying & Labor & $\begin{array}{l}\text { Labor cost/day, establish } \\
\text { surface topographic profile }\end{array}$ & d & 220 & 150 & 260 \\
\hline Tipping fees & Unit costs & $\begin{array}{l}\text { Dumping and grading wastes at } \\
\text { new site }\end{array}$ & tonne & 110 & 110 & 110 \\
\hline Transportation & $\begin{array}{l}\text { Labor/ } \\
\text { equipment }\end{array}$ & $\begin{array}{l}\text { 30-ton dump truck/dump/driver, } \\
\text { based on one-way hauling } \\
\text { distance, return trip } \\
\text { included }\end{array}$ & tonne-km & 0.096 & 0.060 & 0.128 \\
\hline Transportation & $\begin{array}{l}\text { Labor/ } \\
\text { equipment }\end{array}$ & $\begin{array}{l}\text { 15-ton dump truck/driver, } \\
\text { based on one-way bauling } \\
\text { distance, return trip } \\
\text { included }\end{array}$ & tonne-km & 0.110 & 0.069 & 0.145 \\
\hline Treatment system & Unit costs & $\begin{array}{l}\text { Typical costs-interpolated } \\
\text { @ } 0.12 \mathrm{MGD}(440,000 \mathrm{~L} / \mathrm{D})\end{array}$ & each & $580 \mathrm{k}$ & $406 k$ & $687 k$ \\
\hline Trench excavation & Labor & $\begin{array}{l}\text { One equipment operator/one } \\
\text { laborer }\end{array}$ & $\mathrm{m}^{3}$ & 0.22 & 0.17 & 0.35 \\
\hline Trench excavation & Equipment & $\begin{array}{l}\text { Tractor or hydraulic backhoe } \\
\text { to excavate trench, sloped } \\
1 / 2 \text { to } 1\end{array}$ & $\mathrm{~m}^{3}$ & 1.16 & 1.16 & 1.16 \\
\hline $\begin{array}{l}\text { Well points, } 2.5 \text { in. } \\
(6.4-\mathrm{cm}) \text { diam }\end{array}$ & $\begin{array}{l}\text { Materials/ } \\
\text { installation }\end{array}$ & PVC, $25 \mathrm{dt}(7.6 \mathrm{~m})$ & $\mathrm{m}$ & 59.3 & 41.5 & 70.3 \\
\hline Well-point fittings & Materials/ & Fittings and accessories & well & 12.0 & 8.40 & 14.2 \\
\hline
\end{tabular}

Source: Adapted with permission from H. L. Rishel, T. M. Boston, and C. J. Schmidt, Costs of Remedial Response Actions at Uncontrolled Hazardous Waste Sites, EPA-600/2-82-035, SCS Engineers, Long Beach, Calif., 1982. 
Table B.2. Landfill O\& $M$ cost componeats

\begin{tabular}{|c|c|c|c|c|c|c|}
\hline \multirow[b]{2}{*}{ Component } & \multirow[b]{2}{*}{ Subcomponent } & \multirow[b]{2}{*}{ Definition } & \multicolumn{4}{|c|}{ U.S. Dollars } \\
\hline & & & $\begin{array}{l}\text { Metric } \\
\text { units }\end{array}$ & $\begin{array}{l}\text { Source } \\
\text { cost }\end{array}$ & $\begin{array}{l}\text { U.S. } \\
\text { low }\end{array}$ & $\begin{array}{l}\text { U.S. } \\
\text { high }\end{array}$ \\
\hline Chemicals & Materials & $\begin{array}{l}\text { Wastewater/leachate } \\
\text { treatment plant chemicals }\end{array}$ & $\begin{array}{l}L / d \\
\text { (influent) }\end{array}$ & 0.025 & 0.025 & 0.025 \\
\hline Electricity & Power costs & $\begin{array}{l}\text { For water treatment plant, } \\
\text { extraction, injection, and } \\
\text { gas control well/pumps }\end{array}$ & kwh & 0.05 & 0.05 & 0.05 \\
\hline Grubbing & $\begin{array}{l}\text { Labor/ } \\
\text { equipment }\end{array}$ & $\begin{array}{l}\text { Assume annual grubbing } \\
\text { (clearing) of brush }\end{array}$ & $\mathrm{m}^{2}$ & 0.19 & 0.12 & 0.25 \\
\hline $\begin{array}{l}\text { Maintenance/repair } \\
\text { diversion ditch }\end{array}$ & Installation & $\begin{array}{l}\text { Assume diversion ditch needs } \\
\text { needs rebuilding } 2 \text { times/ } \\
\text { year after major storms }\end{array}$ & $\mathrm{m}^{3}$ & 2.75 & 1.73 & 3.60 \\
\hline Monitoring & Labor & $\begin{array}{l}\text { For gas monitoring at active } \\
\text { and passive gas control } \\
\text { installations }\end{array}$ & hr & 12.5 & 7.88 & 16.6 \\
\hline Monitoring (analysis) & $\begin{array}{l}\text { Laboratory } \\
\text { costs }\end{array}$ & $\begin{array}{l}\text { For ground water/leachate } \\
\text { monitoring from } \\
\text { monitoring wells }\end{array}$ & sample & 330 & 330 & 330 \\
\hline Monitoring (sampling) & Labor & $\begin{array}{l}\text { For ground water/leachate } \\
\text { monitoring from } \\
\text { monitoring wells }\end{array}$ & $\mathrm{hr}$ & 12.5 & 7.88 & 16.6 \\
\hline Grass mowing & $\begin{array}{l}\text { Labor/ } \\
\text { materials }\end{array}$ & $\begin{array}{l}\text { Use } 58 \text { in. power ride mower, } \\
\text { one operator }\end{array}$ & ha & 93.9 & 66.7 & 111 \\
\hline Operating cost & Labor & $\begin{array}{l}\text { For water treatment plant } \\
\text { operating personnel }\end{array}$ & hr & 10 & 6.30 & 13.10 \\
\hline Operating cost & Labor & $\begin{array}{l}\text { For gas collection system } \\
\text { operating personnel }\end{array}$ & hr & 15 & 9.45 & 19.95 \\
\hline Refertilization & $\begin{array}{l}\text { Labor } / \\
\text { materials }\end{array}$ & $\begin{array}{l}\text { Assume refertilization once } \\
\text { per year }\end{array}$ & ha & 341 & 247 & 395 \\
\hline Water & Materials & Industrial process water & $\mathbf{k l}$ & 0.92 & 0.92 & 0.92 \\
\hline
\end{tabular}

Source: Adapted with permission from H. L. Rishel, T. M. Boston, and C. J. Schmidt, Costs of Remedial Response Actions at Unconirolled Hazardous Waste Sites, EPA-600/2-82-035, SCS Engineers, Long Beach, Calif., 1982. 
Table B.3. Surface impoundment of capital cost composents

\begin{tabular}{|c|c|c|c|c|c|c|}
\hline \multirow[b]{2}{*}{ Component } & \multirow[b]{2}{*}{ Subcomponent } & \multirow[b]{2}{*}{ Definition } & \multicolumn{4}{|c|}{ U.S. Dollars } \\
\hline & & & $\begin{array}{l}\text { Metric } \\
\text { units }\end{array}$ & $\begin{array}{l}\text { Source } \\
\text { cost }\end{array}$ & $\begin{array}{l}\text { U.S. } \\
\text { low }\end{array}$ & $\begin{array}{l}\text { U.S. } \\
\text { high }\end{array}$ \\
\hline Area preparation & Labor & $\begin{array}{l}\text { For area preparation, rake } \\
\text { and cleanup, average }\end{array}$ & $\mathbf{m}^{2}$ & 0.074 & 0.047 & 0.096 \\
\hline Area preparation & Equipment & $\begin{array}{l}\text { For area preparation, rake } \\
\text { and clcanup, average }\end{array}$ & $\mathrm{m}^{2}$ & 0.022 & 0.022 & 0.022 \\
\hline Bentonite, delivered & $\begin{array}{r}\text { Materials/ } \\
\text { shipping }\end{array}$ & $\begin{array}{l}\text { Shipment of bentonite by } \\
\text { rail near job site, } \\
\text { includes materials } \\
\text { and delivery }\end{array}$ & tonne & & 66.4 & 177 \\
\hline Cement pipe, 6 in. & Materials & $\begin{array}{l}\text { Class } 4000, \text { perforated, } \\
\text { asbestos }\end{array}$ & $\mathbf{m}$ & 8.00 & 6.16 & 8.48 \\
\hline Cement pipe, 6 in. & Installation & $\begin{array}{l}\text { Class } 4000, \text { perforated, } \\
\text { asbestos }\end{array}$ & m & 3.10 & 1.95 & 4.06 \\
\hline Discharge trench & Labor & $\begin{array}{l}\text { Including backfill } 3 \mathrm{ft} \\
(1 \mathrm{~m}) \text { deep }\end{array}$ & $\mathbf{m}^{3}$ & 1.97 & 1.24 & 2.58 \\
\hline Discharge trench & Equipment & $\begin{array}{l}\text { Including backfill } 3 \mathrm{ft} \\
\text { (1 m) deep }\end{array}$ & $\mathbf{m}^{3}$ & 1.57 & 1.57 & 1.57 \\
\hline Diversion ditch & Installation & $\begin{array}{l}\text { Construction and } \\
\text { maintenance/repair }\end{array}$ & $\mathbf{m}^{3}$ & 2.78 & 1.75 & 3.63 \\
\hline Drilled holes, 6 in. & $\begin{array}{l}\text { Materials/ } \\
\text { installation }\end{array}$ & Drilled and cased with pipe & $\mathbf{m}$ & 22.3 & 15.6 & 26.4 \\
\hline Drill rig & $\begin{array}{l}\text { Rental (Equip- } \\
\text { ment/labor }\end{array}$ & Crew and light-duty rig & d & 400 & 280 & 470 \\
\hline Excavation & Labor & One equipment operator & $\mathbf{m}^{3}$ & 0.16 & 0.10 & 0.21 \\
\hline Excavation & Equipment & Front-end loader & $\mathbf{m}^{3}$ & 0.65 & 0.65 & 0.65 \\
\hline Excavating/grading, & $\begin{array}{l}\text { Labor } \\
\text { soil }\end{array}$ & $\begin{array}{c}\text { Common borrow (earth), } \\
1000 \text {-ft }(305-\mathrm{m}) \text { haul }\end{array}$ & $\mathrm{m}^{3}$ & 0.22 & 0.14 & 0.29 \\
\hline Excavating/grading, & $\begin{array}{l}\text { Equipment } \\
\text { soil }\end{array}$ & $\begin{array}{l}\text { Common borrow (earth) } \\
1000-\mathrm{ft}(305-\mathrm{m}) \text { haul }\end{array}$ & $\mathrm{m}^{3}$ & 0.76 & 0.76 & 0.76 \\
\hline $\begin{array}{l}\text { Geotechnical } \\
\text { investigation }\end{array}$ & Unit costs & $\begin{array}{l}\text { Includes surveying, test } \\
\text { borings, equipment } \\
\text { mobilization, monitoring } \\
\text { wells, pump tests, report }\end{array}$ & each & 14,500 & 9,500 & 19,500 \\
\hline $\begin{array}{l}\text { Geotechnical } \\
\text { investigation }\end{array}$ & Unit costs & Slurry well testing & each & 2,000 & 1,260 & 2,260 \\
\hline Gravel & $\begin{array}{l}\text { Labor/ } \\
\quad \text { installation }\end{array}$ & $\begin{array}{l}3 / 4 \text { in. screened gravel, } \\
\text { one dozer operator, } \\
\text { one truck driver }\end{array}$ & $\mathrm{m}^{3}$ & 2.48 & 1.56 & 3.25 \\
\hline Gravel & Materials & $\begin{array}{l}3 / 4 \text { in. screened gravel, } \\
\text { one dozer operator, } \\
\text { one truck driver }\end{array}$ & $m^{3}$ & 7.20 & 5.54 & 7.63 \\
\hline Grout curtain & Labor & $\begin{array}{l}\text { Chemical grout, phenolic } \\
\text { resin, 2-grid }\end{array}$ & $\mathrm{m}^{3}$ & 262 & 165 & 343 \\
\hline Grout curtain & Materials & $\begin{array}{l}\text { Chemical grout, phenolic } \\
\text { resin, grid }\end{array}$ & $\mathrm{m}^{3}$ & 56.2 & 43.3 & 59.6 \\
\hline
\end{tabular}


Trable B.3 (continned)

\begin{tabular}{|c|c|c|c|c|c|c|}
\hline \multirow[b]{2}{*}{ Component } & \multirow[b]{2}{*}{ Subcomponent } & \multirow[b]{2}{*}{ Definition } & \multicolumn{4}{|c|}{ U.S. Dollars } \\
\hline & & & $\begin{array}{l}\text { Metric } \\
\text { units }\end{array}$ & $\begin{array}{c}\text { Source } \\
\text { cost }\end{array}$ & $\begin{array}{l}\text { U.S. } \\
\text { low }\end{array}$ & $\begin{array}{l}\text { U.S. } \\
\text { high }\end{array}$ \\
\hline $\begin{array}{l}\text { Header and discharge } \\
\text { pipe, } 8 \text { in. }\end{array}$ & Materiais & $\begin{array}{l}\text { PVC class } 150 \text { pipe, laid in } \\
\text { trench }\end{array}$ & $\mathbf{m}$ & 24.2 & 18.6 & 25.6 \\
\hline $\begin{array}{l}\text { Header and discharge } \\
\text { pipe, } 8 \text { in. }\end{array}$ & Installation & $\begin{array}{l}\text { PVC class } 150 \text { pipe, laid in } \\
\text { trench }\end{array}$ & $\mathbf{m}$ & 9.61 & 6.05 & 12.6 \\
\hline Hydroseeding & Labor & $\begin{array}{l}\text { Seed and soil supplements/ } \\
\text { amendments }\end{array}$ & $\mathbf{m}^{2}$ & 0.0171 & 0.0108 & 0.0224 \\
\hline Hydroseeding & Materials & $\begin{array}{l}\text { Seed and soil supplements/ } \\
\text { amendments }\end{array}$ & $\mathrm{m}^{2}$ & 0.0877 & 0.0675 & 0.0929 \\
\hline Hydroseeding & Equipment & $\begin{array}{l}\text { Seed and soil supplements/ } \\
\text { amendments }\end{array}$ & $\mathbf{m}^{2}$ & 0.0124 & 0.0124 & 0.0124 \\
\hline Mulching & Labor & Mulching hay & $\mathrm{m}^{2}$ & 0.0085 & 0.0054 & 0.0112 \\
\hline Mulching & Materials & Mulching hay & $\mathbf{m}^{2}$ & 0.0210 & 0.0162 & 0.0223 \\
\hline Mulching & Equipment & Mulching hay & $\mathbf{m}^{2}$ & 0.0057 & 0.0057 & 0.0057 \\
\hline Pump, centrifugal & $\begin{array}{l}\text { Equipment/ } \\
\text { installation }\end{array}$ & 3/4-hp pump & esch & 1,600 & 1,600 & 1,600 \\
\hline Pump, submersible & $\begin{array}{l}\text { Labor/ } \\
\text { installation }\end{array}$ & $\begin{array}{l}1 \mathrm{hp}, 4 \mathrm{in} \text {, including } \\
\text { wiring }\end{array}$ & each & 344 & 220 & 450 \\
\hline Pump, submersible & Materials & $\begin{array}{l}1 \mathrm{hp}, 4 \mathrm{in} . \text {, including } \\
\text { wiring }\end{array}$ & each & 424 & 330 & 450 \\
\hline Sheet piling & $\begin{array}{l}\text { Labor/ } \\
\text { equipment/ } \\
\text { installation }\end{array}$ & PMA-22 steel sheet piling & tonne & 100 & 63 & 131 \\
\hline Sheet piling & Materials & $\begin{array}{l}\text { PMA-22 steel sheet piling } \\
\left(22 \mathrm{lb} / \mathrm{ft}^{2}\right)\end{array}$ & tonne & 507 & 390 & 537 \\
\hline $\begin{array}{l}\text { Slurry wall, } \\
\text { installation }\end{array}$ & Installation & $\begin{array}{l}\text { Install slurry compound in } \\
\text { excavated trench }\end{array}$ & $\mathrm{m}^{3}$ & 45.9 & 32.2 & 54.5 \\
\hline Slurry wall testing & Unit cost & $\begin{array}{l}\text { See "Geotechnical investi- } \\
\text { gation," "slurry wall } \\
\text { testing" }\end{array}$ & & & & \\
\hline Soil compacting & Labor & With sheepsfoot roller & $\mathrm{m}^{3}$ & 0.63 & 0.40 & 0.83 \\
\hline Soil compacting & Equipment & With sheepsfoot roller & $\mathrm{m}^{3}$ & 0.86 & 0.86 & 0.86 \\
\hline Sump & $\begin{array}{l}\text { Labor/ } \\
\text { equipment }\end{array}$ & $\begin{array}{l}\text { 16-ft }(5-\mathrm{m}) \text {-deep } \times 8 \text { in. } \\
(20-\mathrm{cm}) \text {-thick concrete, } \\
\text { cast in place }\end{array}$ & each & 820 & 516 & 1,074 \\
\hline Sump & Materials & $\begin{array}{l}\text { 16-ft }(5-\mathrm{cm}) \text {-deep } \times 8 \text { in. } \\
(20-\mathrm{cm}) \text {-thick concrete, } \\
\text { cast in place }\end{array}$ & each & 750 & 577 & 795 \\
\hline $\begin{array}{l}\text { Surface seal, bitu- } \\
\text { minous concrete }\end{array}$ & $\begin{array}{l}\text { Labor/ } \\
\text { equipment }\end{array}$ & 3 in.-(0.08-m)-thick cap & $\mathrm{m}^{2}$ & 1.05 & 0.72 & 1.24 \\
\hline $\begin{array}{l}\text { Surface seal, bitu- } \\
\text { minous concrete }\end{array}$ & Materials & 3 in.-(0.08-m)-thick cap & $\mathrm{m}^{2}$ & 3.00 & 2.31 & 3.18 \\
\hline $\begin{array}{l}\text { Surface seal, clay } \\
\text { cap }\end{array}$ & $\begin{array}{l}\text { Materials/ } \\
\text { installation }\end{array}$ & $\begin{array}{l}6 \text { in. }(15-\mathrm{cm}) \text { clay cap, } \\
\text { includes } 18 \text { in. } \\
(46-\mathrm{cm}) \text { soil cover }\end{array}$ & $\mathrm{m}^{2}$ & 4.82 & 3.50 & 6.41 \\
\hline
\end{tabular}


Table B.3 (continaed)

\begin{tabular}{|c|c|c|c|c|c|c|}
\hline \multirow[b]{2}{*}{ Component } & \multirow[b]{2}{*}{ Subcomponent } & \multirow[b]{2}{*}{ Definition } & \multicolumn{4}{|c|}{ U.S. Dollars } \\
\hline & & & $\begin{array}{l}\text { Metric } \\
\text { units }\end{array}$ & $\begin{array}{l}\text { Source } \\
\text { cost }\end{array}$ & $\begin{array}{l}\text { U.S. } \\
\text { low }\end{array}$ & $\begin{array}{l}\text { U.S. } \\
\text { high }\end{array}$ \\
\hline $\begin{array}{l}\text { Surface seal, clay } \\
\text { cap }\end{array}$ & $\begin{array}{l}\text { Materials/ } \\
\text { installation }\end{array}$ & $\begin{array}{l}18 \text { in. }(46-\mathrm{cm}) \text { clay cap, } \\
\text { includes } 18 \text { in. } \\
(46-\mathrm{cm}) \text { soil cover }\end{array}$ & $\mathbf{m}^{2}$ & 6.18 & 4.51 & 8.22 \\
\hline $\begin{array}{l}\text { Surface seal, fly ash } \\
\text { cap }\end{array}$ & $\begin{array}{l}\text { Materials/ } \\
\text { installation }\end{array}$ & $\begin{array}{l}12 \text { in. }(30-\mathrm{cm}) \text { fly ash cap, } \\
\text { includes } 18 \text { in. } \\
(46-\mathrm{cm}) \text { soil cover }\end{array}$ & $\mathrm{m}^{2}$ & 4.60 & 3.40 & 6.18 \\
\hline $\begin{array}{l}\text { Surface seal, fly ash } \\
\text { cap }\end{array}$ & $\begin{array}{l}\text { Materials/ } \\
\text { installation }\end{array}$ & $\begin{array}{l}24 \text { in. }(60-\mathrm{cm}) \text { fly ash cap, } \\
\text { includes } 18 \text { in. } \\
(46-\mathrm{cm}) \text { soil cover }\end{array}$ & $\mathbf{m}^{2}$ & 6.28 & 4.49 & 8.36 \\
\hline $\begin{array}{l}\text { Surface seal, lime- } \\
\text { stabilized cap }\end{array}$ & $\begin{array}{l}\text { Materials/ } \\
\text { installation }\end{array}$ & $\begin{array}{l}5 \text { in. }(13-\mathrm{cm}) \text { lime-stabilized } \\
\text { cap, includes } 18 \text { in. } \\
(46-\mathrm{cm}) \text { soil cover }\end{array}$ & $\mathrm{m}^{2}$ & 6.05 & 5.24 & 8.04 \\
\hline $\begin{array}{c}\text { Surface seal, PVC } \\
\text { membrane cap }\end{array}$ & $\begin{array}{l}\text { Materials/ } \\
\text { installation }\end{array}$ & $\begin{array}{l}\text { 30-mil PVC membrane cap, } \\
\text { includes } 18 \text { in. }(46-\mathrm{cm}) \\
\text { soil cover }\end{array}$ & $\mathrm{m}^{2}$ & 10.8 & 9.72 & 14.4 \\
\hline $\begin{array}{l}\text { Surface seal, cement } \\
\text { cap }\end{array}$ & $\begin{array}{l}\text { Materials/ } \\
\text { installation }\end{array}$ & $\begin{array}{l}5 \text { in. }(13-\mathrm{cm}) \text { soil cement cap, } \\
\text { includes } 18 \text { in. }(46-\mathrm{cm}) \\
\text { soil cover }\end{array}$ & $\mathrm{m}^{2}$ & 6.05 & 5.24 & 8.04 \\
\hline Surveying & Labor & Labor costs/day & d & 220 & 150 & 260 \\
\hline Tipping fee & Unit costs & Fee paid at secure landfill & tonne & 110 & 110 & 110 \\
\hline Transportation & $\begin{array}{l}\text { Labor/ } \\
\text { equipment }\end{array}$ & $\begin{array}{l}\text { 30-ton dump truck/driver, } \\
\text { based on one-way hauling } \\
\text { distance, return trip } \\
\text { included }\end{array}$ & tonne $/ \mathrm{km}$ & 0.096 & 0.060 & 0.128 \\
\hline Transportation & $\begin{array}{l}\text { Labor/ } \\
\text { equipment }\end{array}$ & $\begin{array}{l}\text { 15-ton dump truck/driver, } \\
\text { based on one-way hauling } \\
\text { distance return trip } \\
\text { included }\end{array}$ & tonne $/ \mathrm{km}$ & 0.110 & 0.069 & 0.145 \\
\hline Treatment plant & Unit costs & $\begin{array}{l}\text { Costs interpolated from } \\
\text { Dodge Guide } 1980 \\
\text { with SCS estimate }\end{array}$ & $L / d$ & 0.89 & 0.70 & 1.18 \\
\hline Trench excavation & Labor & $\begin{array}{l}16 \mathrm{ft}(5 \mathrm{~m}) \text { deep } \times 3 \mathrm{ft} \\
(1 \mathrm{~m}) \text { wide, one equipment } \\
\text { operator, one laborer }\end{array}$ & $\mathrm{m}^{3}$ & 0.22 & 0.17 & 0.35 \\
\hline Trench excavation & Equipment & $\begin{array}{l}16 \mathrm{ft}(5 \mathrm{~m}) \operatorname{decp} \times 3 \mathrm{ft} \\
(\mathrm{l} \mathrm{m}) \text { wide, backhoe } \\
\text { excavator, sloped } 1 / 2: 1\end{array}$ & $\mathrm{~m}^{3}$ & 1.16 & 1.16 & 1.16 \\
\hline Well fittings, 8 in. & Materials & PVC & well & 127 & 97.8 & 134.6 \\
\hline Well fittings, 8 in. & Installation & PVC & well & 98 & 61.4 & 128.4 \\
\hline Well points & $\begin{array}{l}\text { Materials/ } \\
\text { installation }\end{array}$ & $16 \mathrm{ft}(4.9 \mathrm{~m})$ long & m & 59.3 & 40 & 70 \\
\hline Well-point fittings & Unit costs & Fittings and accessories & well & 12.0 & 8.40 & 14.2 \\
\hline
\end{tabular}

Source: Adapted with permission from H. L. Rishel, T. M. Boston, and C. J. Schmidt, Costs of Remedial Response Actions at Uncontrolled Hazardous Waste Sites, EPA-600/2-82-035, SCS Engineers, Long Beach, Calif., 1982. 
Table B.4. Surface impondment of orerbead and maintennince

\begin{tabular}{|c|c|c|c|c|c|c|}
\hline \multirow[b]{2}{*}{ Component } & \multirow[b]{2}{*}{ Subcomponent } & \multirow[b]{2}{*}{ Definition } & \multicolumn{4}{|c|}{ U.S. Dollars } \\
\hline & & & $\begin{array}{l}\text { Metric } \\
\text { units }\end{array}$ & $\begin{array}{l}\text { Source } \\
\text { cost }\end{array}$ & $\begin{array}{l}\text { U.S. } \\
\text { low }\end{array}$ & $\begin{array}{l}\text { U.S. } \\
\text { high }\end{array}$ \\
\hline Chemicals & Materials & $\begin{array}{l}\text { Wastewater/leachate treatment } \\
\text { plant chemicals }\end{array}$ & $\begin{array}{l}\mathrm{L} / \mathrm{d} \\
\text { (influent) }\end{array}$ & 0.025 & 0.025 & 0.025 \\
\hline Electricity & Power costs & $\begin{array}{l}\text { For water treatment plant or } \\
\text { extraction, injection, and } \\
\text { gas control wells/pumps }\end{array}$ & $\mathbf{k w h}$ & 0.05 & 0.05 & 0.05 \\
\hline Refertilizing & Labor/materials & Assume fertilizing once/year & $\mathbf{m}^{2}$ & 0.0060 & 0.0046 & 0.0064 \\
\hline Grass mowing & Labor/equipment & $\begin{array}{l}\text { Assume grass mowing } 6 \text { times/ } \\
\text { year, minimum } \$ 10 / \text { visit }\end{array}$ & $\mathrm{m}^{2}$ & 0.0015 & 0.00097 & 0.002 \\
\hline Grubbing & Labor/equipment & $\begin{array}{l}\text { Assume annual grubbing } \\
\text { (clearing) of brush }\end{array}$ & $\mathbf{m}^{2}$ & 0.19 & 0.12 & 0.25 \\
\hline $\begin{array}{l}\text { Maintenance/repair, } \\
\text { diversion ditch }\end{array}$ & Installation & $\begin{array}{l}\text { Assume twice annual ditch } \\
\text { repair }\end{array}$ & $\mathbf{m}^{3}$ & 2.78 & 1.75 & 3.63 \\
\hline Monitoring (analysis) & $\begin{array}{l}\text { Laboratory } \\
\text { costs }\end{array}$ & $\begin{array}{l}\text { For ground water/leachate } \\
\text { monitoring from monitoring } \\
\text { wells }\end{array}$ & sample & 330 & 330 & 330 \\
\hline Monitoring (sampling) & Labor & $\begin{array}{l}\text { For ground water/leachate } \\
\text { monitoring from monitoring } \\
\text { wells }\end{array}$ & h & 12.5 & 7.88 & 16.6 \\
\hline Operator personnel & Labor & $\begin{array}{l}\text { For operation of water treat- } \\
\text { ment plant and sampling for } \\
\text { monitoring }\end{array}$ & $\mathbf{b}$ & 12.6 & 7.92 & 16.3 \\
\hline
\end{tabular}

Source: Adapted with permission from H. L. Rishel, T. M. Boston, and C. J. Schmidt, Costs of Remedial Response Actions at Uncontrolled Hazardous Wastes Sites, EPA-600/2-82-035, SCS Engineers, Long Beach, Calif., 1982. 
ORNL-6317

\section{INTERNAL DISTRIBUTION}

1. B. D. Chilton

2. J. T. Ensminger

3. S. V. Kaye

4. C. J. Oen

5. P. T. Owen

6. H. A. Pfuderer

7. D. E. Reichle

8. S. S. Talmage

9. T. Tamura
10. P. J. Walsh

11. Central Research Library

12-13. Information Research and Analysis

14-15. Laboratory Records Department

16. Laboratory Records ORNL-RC

17. ORNL Patent Office

18. ORNL Y-12 Technical Library

\section{EXTERNAL DISTRIBUTION}

19-22. L. R. Anspaugh, Lawrence Livermore National Laboratory, P.O. Box 5507, Livermore, CA 94596

23-27. B. W. Church, Nevada Operations Office, U.S. Department of Energy, P.O. Box 14100, Las Vegas, NV 89114

28. G. R. Eisele, Medicine and Health Science Division, ORAU, P.O. Box 117, Oak Ridge, TN 37830

29. E. H. Essington, Los Alamos National Laboratory, Environmental Sciences LS-6, 118 Balboa Drive, Los Alamos, NM 87544

30. R. O. Gilbert, Pacific Northwest Laboratory, P.O. Box 999, Richland, WA 99352

31. W. A. Howard, Nevada Operations Office, U.S. Department of Energy, P.O. Box 14100, Las Vegas, NV 89114

32. R. R. Kinnison, Pacific Northwest Laboratory, P.O. Box 999, Richland, WA 99352

33. E. M. Romney, University of California, Laboratory of Biomedical and Environmental Sciences, 900 Verteran Ave., Los Angeles, CA 90066

34. J. H. Shinn, Lawrence Livermore National Laboratory, P.O. Box 5507, L-524, Liveremore, CA 94550

35. Office of Assistant Manager, Energy Research and Development, U.S. Department of Energy, Oak Ridge Operations Office, Oak Ridge, TN 37831

36-37. Office of Scientific and Technical Information, U.S. Department of Energy, P.O. Box 62, Oak Ridge, TN 37831 


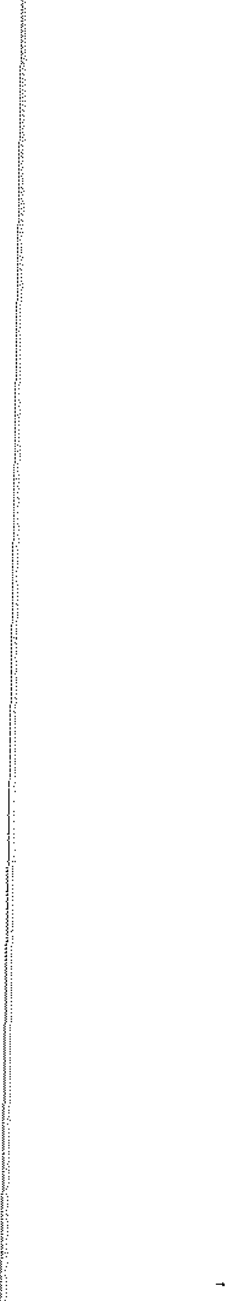

3 
crc 